\title{
DISSECANDO O GEN
}

S. de Toledo Pha Jor.

Professor de Zoologia, Anatomia e Fislologia da Escola Superior de Agricultura "Luir de Queiroz" da Universidade de São Paulo 
ronhicem-se da literatura alguns casos bem interessantes de fatores genéticos, que sendo simples, isto é, comportando-se na segrrgaçán como uma unidade mendeliana singela, produzem, no entanto, efeitos multiplos. Seria, por exemplo, o caso do sen $W$ da Drosophila, que modifica a cor dos olhos e da membrana envolvente dos testículos e bem assim altera a forma da espermateca, a duraçáo da vida, etc. Hste e outros gens que agem? da mesma maneira săo designados por gens pleiotrópicos.

Como poderiamos interpretar a açăo dessses gens? Digamos iniciaimente que ninguém jamais conseguiu explicar o mecanismo intimo segundo o qual os gens desempenham no organismo o papel que lhes es atribuido. Os genetistas se limitam a afirniar que tais ou tais efeitos se devem atividade especifica de tais ou tais gens. Mas se lhes perguntarmos de que maneira trabalha o gen no desempenho da sua funçăo, năo saberåo responuler ou darăo respostas somente aceitáveis por aquêles que noco queiram se dar ao trabalho de subncte-las a um exare critico. Dizer-se, por exemplo, que dada coloraçáo das pétalas ie uma flor se deve a um gen que altera a reaçáo do melo e tâo certo como dizer-se que a asa vestigial de um Diptero se prende a atividade de um gen que inibe o desenvolvimento norinal do disco imaginal correspondente. Porém, modificar a reação do meio ou opor-se ao desenvolvimento de discos imsginais são os fatos e năo as explicaçōes. O que queremcis saber é justamente como trabalham os gens responsáveis, para mcdifica: o pH do meio ou para obstar ao desenvolvimento da asa. Ninguém até hoje foi capaz de responder a essas questós fundamentais de modo satisfatório. verdade que explicaçốes têm sido tentadas. Porém; enquanto umas caem logo ao primeiro esbarro da critica, outras subsistem como meras hipóteses à espera de uma demonstraçáo que ainda estamos longe de poder encontrar. Vejamos um exemplo. A coloraçán de certas flores se deve à presença no citoplasma das células epidermais de um complexo organico do grupo das antocianinas. Eis o fato. De conformidade com os resultados das experiencias ur cruzamentos concluiu-se que as antocianinas s.6 !nbnradas por gens. Dando isso por demonstrado, temos al outro ricto. Como poderá um gen elaborar uma antocianina? Aqui tenius o problema. Simplesmente se desdobrando e abandonando para o nucleo e depois para o citoplasma o produto dêsse desdobramento. E aqui, a explicaçáo.

Analisemos essa explicaçăo. Que um gen, pela faculdade de auto-sintese de que goza e que é a sua principal caracteristica (DORZHANSKY 1943) possa fabricar uma certa quantidade da 
sua frón encontra, náo passa de uma especulaçáo como tantas outras que săo tomadas muito a sério pelos divulgadores de matéria clentifica e apresentadas ao publico como se constituissem explicaḉes para os fenomenos biológicos. O primeiro produto do gen seria entâ. uma cópia livre do próprio gen (FAIDANE 1941), que assim poderia entrar em reaçסes com nutros gens iguaimente livres ou com produtos diversos do nucleo ou do cltoplasma, para determinar no organismo o carater que the atribuido.

Achc muitc pouco provável que essa possa ser a origem dos produtos genicos. Primeiro, porque isso nos leva a uma concepça kem extravagante acerca da constituiçăo quimica dos cromossumiris, que se nos apresentariam como rosários das mais diversas e heterogêneas substancias. Um cromossomio com cem gens seria ume cadeia química formada por cem substancias diversas, algumas das quais extremamente complexas. Haveria gens aglutininas, gens precipitinas, gens antigenos, gens hormonios, gens enzimas, gens co-ênzimas, gens proteinas, gens hidrucarbunados, gens ácidos, gens bases, gens minerais, gens orgânicrs. gens solúveis e gens insolúveis na água. E seria muito de se extranhar o fato desses gens enquanto nos cromossomios năn reqgirem uns com outros, conservando, pelo contrário, indefinidamente, a mesma constituiçăo, a despeito de poderem se aproximar e mesmo se tocar, dada a condiçáo de extrema distersâo e de enovelamento em que se encontram os cromissconios no estado metabolico (repouso) da célula. Aliás, essa é quie deve ser a verdadeira conduta dos gens e o que se torna ejtác extranhável é o fato dos gens libertos perderem as suas propriedades fundamentais: multiplicaçăo por auto-sintese e preservaçăo da sua constituiçăo. Fica muito dificil de compreender como possam os gens antocianidinas (cianidinas, pelargonidinas. delflisidinas) se opor, quando concatenados no corpo dos romussomios, a metilizaçăo que os transforma, quando livres, nas antocianinas (peonidina, petunidina, malvidina, etc.) responsáveis pela coloração das plantas! Parece mais razoável de cuinformidade com os conceitos teóricos que dominam a moderna genética, qu? o citoplasma das células entrasse com a matéria prima cujas reaçós os gens apenas controlassem. Entretanto, se se vier um dia a confirmar a especulaçăo de HALDANE, sezundo a qual os produtas genicos seriam cópias livres das respectivos gens, entâo teríamos os gens reagindo químicamente urs com ou outros e se transformando, eles, os gens, objetiva, material, substancial e corpuscularmente nos caracteres a eles devidos. Se uma flor e vermelha por conter uma an- 
tocianina que em determinado meio se apresenta com essa corr, se a antucianina é uma antocianidina metilizada e se a antocianidina é a copla livre do gen, segue-se que gen e caráter, em essência, săo uma e a mesma cousa. Desse modo desaparecer $\&$ a diferença entre genotipo e fenotipo e bem assim a epigênese cederá o seu lugar a preformaçáo e a Genética caminhará para trás e pouco a pouco atingirá o seu ponto de partida. Ress?lta dâl a inconsistencia de certas explicaçర̋es.

Uma das hipotesses mais importantes da genética e que consititui a base sobre a qual se assentam as pedras fundamentais desse ramo monumental da Biologia é aquela que considera os zens como sendo particulas materiais alinhadas nos cromosscmios, diferindo entre si pela constituiçæo e por propriedades especificas. Nesse concelto hipotético, que resume a definiçăo do gen, se encontram pelo menas duas outras hipoteses: que o gen seja constitucionalmente diverso dos outros e que, talvez por esse motivo, tenha propriedades tambem diferentes. I ffeliamente 0 abuso de linguagem ou a força de expressăo tăo comuns em aulas e conferencias converteram assunçr̂es ainda năo demonstradas em fatos consumados, transformando conceltos hipotéticos em realidades objetivas. (Cf. PIZA 1944). Entretanto, estudando os cromossomios pelos método: mais modernos e perfeitos de que dispomos, nada encontramos nêles que corresponda a uma diferenciaçáo estrutural de partes. Seráo por ventura os cromomérios os representantes materiaiz dos gens ? Já JOHANNSEN (1926) afirmara num livro qie sa torncu clássico, que

"Fine dem morphologischen Geiste naheligende Gefihr ist die, das man chromomeren - diese organoiden Gebiide - mit genen identifizieren möchte". (Pag. 648).

Fazendo há alguns anos (PIZA 1930) comentários acerca da impropriedarle dos cromomérios para representarem as gens, cheguei à conclusăo de qủe essas particularidades morfológicas provàvelmente năo constituem diferenciaçōes regionais da estrutura cromossomica e sim meros acidentes de um substrato que bem poderia ser de constituiçăo uniforme. Recentemente RIS (1345), tratando pelo Kcn os cromassomios de vários Ortopteros, conseguiu distender os cromomerios, que assim se revelaram constituidos por simples acumulaçóes regionais das espirns de um cordăo de aspecto regular. Também se poderia arguir se os diccos assinalados com grande evidencia nos cromassomius salivares da Drosophila, da Sciara e de outros Dipteros nóo seriam as gens de que a genética tanto necessita. 
Quanto : esse particular poderiamos responder que a despeito dos in: imeros trabalhos já realizados quer no dominio da morfologia, quer no da quimica, nada se encontra na literatura capaz de demnnstrar a mais leve diferença qualitativa entre os disers cromossumals. Podemos mesmo afirmar que apesar de tantos estudos náo se conseguiu sequer compreender a estrutura dos cromnssomios salivares. Ainda se discute sobre o numero de cromonemas neles presentes e sobre as particularidades estruturgis ou quimicas que possam distinguir as discos, das zonas interdiscäls. Até mesmo o conceito de discos tem mudado ultimamente. KODANI (1912) concluiu dos efeltas do tratamento das glandulas salivares da Drosophila por hidroxido de sodio e uréla, qua os discos náo passavam de alças opostas, formadas de cada lado, por dois dos quatro cromatídios presentes nos cromusscmios. Por seu turno RIS \& CROUSE (1945) acham que os crumossomios salivares da Sciara são formadas por fllamentos uniformes e que os discos nada mais săo que erronea interpretaça de aspectos devidos à complexa espiralizaçăo regional de un feixe de cromonemas. Há até quem pense (HINTON 1946) que os cromossomios salivares sejam constituidos por uma série desrontinua de elementos genicos (as discos) separados por espaços tomados por substancias nko genicas vindas do exterior (nucleoplasma). E verdade que tanto a regizo das alças de KODANI como a das espirais complexas de RIS \& CROUSE prodem corresponder a uma diferenciaçáo estrutural de um substrato aparentemente homogeneo. Porem, mesmo que os segmentos em que assas particularidades (discos, alças, espirais) se iazem notar sejam estruturalmente diferentes dos que se lhes inte:phem nada indica que eles divirjam qualitativamente entre si. Ve-se do que acabámos de expor, que objetivamente falando-se, nada de material existe, que possa ser tomadc. como suporte dos gens, considerando-se esses elementos com a significaçán que a genética lhes dá.

St: como vimos, náo foi ainda possivel decompor os cromossomios em tantos segmentos distintos quantos exige a teoria do gen crrpuscular, dificilimo será por certo localizar neles as chama.tss funçסes genicas. Mas o genetista poderá com razo.o arglimentar que 0 fato de se nåo ter ainda podido reconhecer rogiøes distintas ao longo dos cromossomios, nå prova que essas regioes nåo existam. Perfeitamente. Porém, se o genetista chegsor ao ponto de afirmar que a falta de provas a favor náv vale como prova em contrário, terá simplesmente demcnstrado a caréncia completa de argumentos em apolo da tese que pretende defender. Pode-se, pois, concluir, que a teorla do grid-particula baseia-se em hipóteses ainda por demonstrar a que por consegulnte, quem fala atualmente em gen, ape- 
nas i.e refere a um simbolo que se encontra por enquanto muito longe à tăo almejada realidade.

Para mostrar a situação embaraçosa do genetista que procura definder a idéia de um gen-particula, basta transcrever aqui um pequeno trecho de DOBZHANSKY (1941):

"According to Goldschmidt, genes must either be separate by impregnable walls, or else they do not exist at all. If this were the only choice, his conclusion would be justified. But surely many more than these two alternatives are to be considered. Discrete entities like genes may he integrated into sistems, chromosomes, functioning as such. The existence of organs and tissues does not preciude their cellular organization. Moreover, the degrec of independence of cells varies from tissue to tissue; ieucocytes may behave like so many amoebae, meristematic cells are associated more intimately, and in muscle fibers the baunderies between cells seem to disappear entirely" (pag. 110).

Vê-se por ai que a argumentação de DOBZHANSKY é fraca e contraditoria. Quando ele afirma que entidades discretas como os gens podem se achar integradas em sistemas funcionanc" coino tais - os cromossomios, está, evidentemente sem - querer, suprimindo uma das mais importantes caracteristicas do gen, isto é, a sua independencia funcional. De fato, se os gins furem independentes, podendo cada qual sofrer alteraçōes rautacionais ou se separar dos seus vizinhos sem que estes se alterem confurme escreve DOBZHANSKY à página 106 do seu importante livro, entáo o cromossómio, do ponto de vista genético, năo constituirá um sistema. Se, pelo contrário, o cromossomio for realmente um sistema, ele deverá, como tal, sentir a infiuê cia ta alteraçăo ou supressáo dos elementos que o integra:n e nesse caso o gen deixará de ser independente. De ouiro larto 3 fato dos tecidos serem constituidos por celulas, nada di: conum apresenta com o cromossómio considerado como um sisteina de gens. Os tecidos năo passam de um agregaao de elementos identicos, executando independentemente as mesmas ativiradas e por esse motivo năo constituem sistemas. Ao passo que o crimossómio, como sistema, é formado por um conjunto de orgăos diferentes (os gens), dependendo estreitamente uns dos outros para o desempenho da funçăo atribuida ao todo.

F.stainos, por conseguinte, diante de um dilema : ou o cromossomio é um sistema e o gen deixa de ser independente, ou o ger é independente e o cromossomio deixa de ser um siste- 
ma. O qiie nác pode existir é um sistema (o cromossómio) de orgár.s in lependentes (os gens) como pretende DOBZHANSKY. Arguinentos citologicos, fisiológicos e genéticos apoiam a conclusáo de que o cromossomio é de fato um sistema e assim sendo funcinna a maneira de qualquer outro sistema, isto é, como um todo. (Cf. PIZA 1939, 1941 e GOLDSCHMIDT 1938, 1940). O gen ielxando porisso de ser independente, perde a sua individualidade, a sua autonomia e desaparece como pretendem GOLDSCHMIDT e PIZA.

Enquanto a genética não abrir måo do conceito insustentável de gen-particula ela terá a cada passo que apelar para hipoieses subsidiárias, algumas das quais verdadeiramente pueris, snm o que seu mecanismo emperra ou deixa de funcionar. Veja-se a títulc de exemplo a ingenuidade de uma das explicaçós mals generalizadas das que se tem proposto ao fenomeno conhecido por "efeitos de posigio".

Jomo se sabe, por "efelto de posiçăo" designa-se uma variaçă hereditária devida à mudança de lugar do gen responsável, o que tanto pode ocorrer em consequencla de uma inversăo de urn segmento cromossomal, como de uma translocaçăo para o crumosstimio homologo ou parn outro qualquer.

Após o exame detalhado dos cromossomios salivares da Drosiphila os autores que tem estudado o fenomeno chegaram a cor.clusano de que realmente, em todos esses casos, nada mais se pode constatar além de uma transposiçăo do "locus" em que se encontra situado o gen responsável. Desse modo estabelecaram que os efeitos do gen nåo dependem somente da sua constituiçăo, mas também da posiçăo que ocupa na série formada, pelus outros gens. Ou, em outras palavras, que o gen sofre a influencia dos seus vizinhos, uma vez que mudando de vizinhaiiça produz um efeito diferente do que produzia antes. Para exp'icar isso alguns autores elaboraram uma teoria que se enc.ontra resumida em GOLDSCHMIDT (1938) DOBZHANSKY (i94i). STURTEVANT \& BEADLE (1940) e que consta mais ou menos do seguinte:

S.S. p:odutos elaborados pelos gens reagem uns com os outros ou erităo crm substancias formadas na célula pela açăo daqueles produtos. Supondo que de dois gens vizinhos A e B 0 primeirc. (A) reage com uma certa substancia do melo celular (x) danclo um produto (C) que deve sofrer a açăo do outro gin (.B), segue-se que se o gen $\mathbf{B}$ mudar para uma pọsiçăo distarte de $A, n$ produto por ele elaborado levará mais tempo para cntrar am contato com a substancia $\mathbf{C}$ resultante da acáo de $\mathbf{A}$ sobic $\mathbf{X}$, cuja concentraçio e maior nas proximldades de A. Nessas condiçóes um outro produto genico poderá entrar em 
relaçăo com $\mathbf{C}$ antes que o produto de $\mathbf{B}$, alterando-se dal por diante o curso normal das reaçbes.

Vejamos quantas incongruencias existem nessa explicaçbo.

Em primeiro lugar ficou estabelecido que as reaçoes devidas a atividades genicas são especificas e se processam numa ordem detinida, de sorte que cada reaçáo prepara o melo para a reaçáo segilinte. Portanto, se o melo $\mathbf{C}$ resultante da açéo de A sobre $X$ é o melo especifico para a atividade de $B$, segue-se que nenhilm outro gen, em consequencia da sua especificidade, pode tralialhar nesse melo. somente depois que $\mathbf{B} 0$ transformar, que um novo gen poderá entrar em ação. Desde que o genótipu nạo sofreu alteraçáo com a simples mudança de lugar do gen, evidente que o único resultado que se poderia esperar era um pequeno atraso sem consequéncias no inicio da reaça entre o produto de B e o seu substrato especifico C. Psse pequeno atrass seria compensado pela maior quantidade de substancia C que o produto de B iria encontrar já formada. De mais a mais a explicaçáo esquece-se de que os gens trabalham no nucleo em repcusn e que nesse estado os cromossomios se encontram enovelados e emaranhados, variando de celula em celula, bem como, no mesmo núcleo, de momento para momento, a distancia que separa dois gens quaisquer do mesmo cromossomio ou de cromossomios diferentes. fícil de compreender, que uma simples curvatura de um segmento cromossomal distendido pode aproximar dois gens que uma inversto separara por uma longa axtensao. (")

A idéla te que os gens passam reagir diretamente uns com os oitros e naco por intermédio dos seus produtos para explicar os efeltos de posiçáo levaria o genetista aos conceitos de PIZA e de GOLDSCHMIDT segundo as quais os cromossomios funcio-

(*) J: esi-iva escrito êste artigo quando me chegou às măos um trabalho de Goldschmidt (1946) do qual destaco o seguinte trecho, que enceria um ronceito perfeitamente identico ao meu: "There are many s.rious objections to such a view, even assuming its possibility from a point of view of chemical kinetics see below). The chromosomes ofe the resting nucleus are probably in completiy stretched condition and are floating in a liquid medium. It is hardly possible that ii the case of a one - or two-band inversion the actual change in. order of "genes" could influence primary reactions in their neighborword. except by diffusion along the chromosomal surface. In such a cet-ip, further, any point of a chromosome has a chance of meeting airy other poirt of the same or other chromosome, and this meeting should r roduc" a position effect each time”. (Pag. 18). 
nam somo um todo. Realmente, se um gen B, acostumado a trabalhar sntrc 1 e C (como por exemplo no cromossomio ABCDAF) passa a funcionar diferentemente so porque uma inversăc o levou para as proximidades de $\mathbf{F}$ (AIDCBF) e como năo se pode adinitır que $\mathbf{B}$, reagindo com $\mathbf{F}$, se modifique sem modificar tambem o seu novo vizinho, segue-se que $\mathbf{F}$ igualmente se altera. Os gens $\mathbf{E}$ e $\mathbf{A}$ do mesmo modo se alteram pela mudança da posiçăo do primeiro. Mas como qualquer modificaçăo sofrida por um gen acarreta uma modificaçåo compensadora do ger vizinho no sentido de restabelecer o equilibrio das reaçరes, cor:clui-se que todos os gens se modificam em consequencla da inversto. $O$ mesmo se daria com as mutaçбes. A transformaçăn de $\mathbf{B}$ em $B^{\prime}$ modificaria $A$ e $C$, que passariam a $A^{\prime}$ C C' tete ultimo. reaginc'o com $D, 0$ transformaria em $D^{\prime}$ e dentro ym pouco sodo o cromossomio estaria transformado. Uma alteraça: localizada transformaria, por conseguinte, um todo primitive T, num novo todo 'T', como pretende PIZA.

Efeitos de posicăo devidos a inversóes de segmentos muito pequenos, que podem corresponder até a um único disco dos cromossomios salivares da Drosophila (GOLDSCHMIDT 1944) póem em séria dificuldade a teoria das distancias dos produtos genicos: (Cf. GOLDSCHMIDT 1946).

O fato das inversóes dos cromossomios da Sciara, que podem ser ana!lisadas nas glandulas salivares desse Diptero com - mesma rigor com que o săo na Drosophila, năo produairem efeitrs de posição (CARSON 1944), a inexistencia quase que absoluta jesse fenomeno no milho, tăo intensamente estudado do punto de vista cito-genético e a ocorrencia de inversős na acompanhadas de efeitos de posiçăo na própria Drosophila levam-nos a pensar que ainda náo se conseguiu entrar na pista que cond'zirá à soluçăo desse importante problema.

A Idéia de gen copuscular levou a genética a necessidade de explicar o pareamento dos cromassomios homólogos na melose como sendo devido a uma atraçăo ponto por ponto. Conforme nccstrel em outro trabalho (PIZA 1944), nso se encontra em citologia nenhuma pvidencia de uma tal atraçăo inter-genica. Há, pelo contrario, bons argumentos de caráter objetivo que apoiam 8 idéla de que os cromossómios se atraem globalmente e que a coincidencia dos pontos correspondentes nos dols elementos em conjugação é mera consequência da polaridade desses elementis e ta justaposiçáo dos cinetocores necessária a sua regular orlentaçăo e separação. Os estudos citologicos efetuados por MC CLINTOCK (1945) com Neurospora crassa, na qual os cromossdmios primeiramente se contraem, para depols se parearem e en seguida distenderem-se, suportam o conceito de uma 
atração g'obsl. O melhor argumento citológico que se costums invocar como suporte de uma atraçáo ponto por ponto é o modo particular de pareamento dos cromossomios salivares d:.s Diptr:Yos, nos casos em que um dos parceiros sofreu inversão dn um segmento mais ou menos longo. Nessas condiçסes, confornic se sai e. um das cromossomios do par forma uma alça que o uutro percorre em sentido contrário no segmento correspondente à invrrş̌́o tsse argumento, porem, perdeu multo do seu primitivo valor desde que foi mostrado (PIZA 1942), com base em observaçōes realizadas com o Tityus bahiensis, que a existencia de una fíce de pareamento nos cromossómios (dorso-ventralldade) levaria aos mesmos resultados se o segmento invertido, ao se soldar aos outios dois segmentos, o fizesse de tal forma, que a sua face de pareamento ficasse em oposiçáo a face de pareamento daqueles. Mesmo que se năo recorresse à dorso-ventralldade, poderiamos interpretar as alças dos cromossomios nos ca. sos de inve: sáo, como sendo devidas à tendencia natural que tem o segmento invertido de acompanhar a polaridade do segmento correspondente do outro cromossomio.

ije areitarmos a existencia da polaridade segundo os dois eixos dos cromossómios e admitirmos a possibilidade de alteraçáo ila folaridsde de um segmento invertido ou translocado, o que poderia depender das dimensoes do segmento e da sua malor ou menor proximidade do cinetocore e se de outro lado reconhecermos tue no pareamento a influencia da polaridade longitudinal pode sobrepujar ou nzo a influencia da dorso-ventralldade, estariamos preparados para compreender as situaços em que năo há formaçăo de alças na regiáo da inversăo e aqueles em que năo há pareamento apesar de năo ter havido inversăo, tal como observou CAPSON (1944) na Sciara.

Um fato que a meu ver enfraquece grandemente a idei: clássira de ume atraçáo gen-a-gen é tírado do comportamento dos cromossómios que sofreram mutaçбes. Como sabemos, na homozigose, o mesmo gen se acha representado duas vezes, em posiçôes corrosponjentes, no corpo dos cromossómios homólogos. Sofre:zdo ur dêles uma mutaçăo, tão intensa que é capaz de transformar completamente o organismo, convertendo integral mentf a femea em macho, como se dá, por exemplo, com o ge l recessivo "transformer" (STURTEVANT 1945) e com tantos outros de efeitos tão drásticos que chegam a impedir o desenvolvimento (gens letals), nem porisso se assinala qualquer alteraçáo cla atraçăo entre esse novo gen e o primitivo. Parece que se pode conclutr, que, se os gens $A$ e $A$ se atraem especificamente, a ytraçáo deve desaparecer em virtude da mutação. Mas comi em heterozigose os gens continuam a se atrair do 
mesmc nıodo. segue-se que a atraçăo năo é especifica e portanto nzo é um atributo génico. Aliśs, no conceito de homologia genica nác ss leva em conta a constituiça intrinseca dos gen:" de sorte que dois gens homologos podem diferir muito mais profundamente entre si, do que dois gens heterologos quaisquer. E visio que os gens homólogos se atraem qualquer que seja a sua constituiçăo, como compreender a năo atraço entre os gens heterólcgos ou entre aqueles que se encontram no mesmo cromossomio?

A genética, sob diversos aspectos, muito se parece com certas religizes. St os interpretes da Biblia se valessem dos ensinamentcs da ciencia, poderiam com facllidade oferecer versobes aceitiveis de a!gumas passagens, que tomadas ao pé da letra, sảo vardateiros absurdos. Mostrel recentemente, que se tomarmos a costela de Adåo como significando um cromossomio, teremos uma explicaçăo razoável do episódio da formaça de Eva. (PIZA 1946). Estou, porém, seguro, de que o trecho biblico continuará \& ser tomado ao pé da letra continuando Bva a ser consilerala como tenao sido feita de uma costela de Adlo.

A questão do gen se parece com a da costela de Adko: Alguns intérpretes da genética (que no caso funciona como a Biblia) firmaram a respeito do gen um concelto que em multos nartisulares chega a ser absurdo... Mas preferem assim a ve-lo despidr, das faculdades verdadeiramente miraculosas que the conferiram.

F.m citro trabalho afirmei que o pareamento dos cromossómios nạo passa de uma copulaçăo, copulando os cromossomios assim como copulam os gâmetas e os nucleas gameticos. (PIZA 1944). A copulaçáo dos cromossómios homólogos, que a de fato especjfica, se poderá explicar a semelhança da copulaçáo gamética o:i da conjugaçăo dos ciliados, com base no produçă de uma substáncia pelos membros de cada par, substancia essa que agiria como uma sorte de fertilizina, determinando a !nniăo dos elementos homólogos. Entretanto, para manter a indecendéncia funcional dos gens, o genetista preferirla nao tomar conhecimento de um mecanismo incomparavelmente mais simples e de acórdo com fatos conhecidos da fisiologia da reprctuçăo, pa!a aceitar a situaçăo complicadissima de uma açăo espacificia entre os gens, cada um dos quais elaboraria uma substancia diferente da elaborada pelos demais e que irla atuar exclusivamente sobre o gen homólogo. Para o pareamento de um crorrossomic provido de cem gens seriam necessurias cem substancizis ativas diferentes, agindo especificamente. Consideranjo-se. porém, o cromossómio, como uma unidade morfologica e funcional, que realmente é, uma unica substancia pro- 
move"ia o riesmo resultado. Essa extraordinária simplificaçăo custaria. porem, o abandono da idéia de um gen corpuscular independerte. Convenhamos que é extremamente penoso abandonar unia litéia firmada em conviç̧סes aparentemente inabaláveis. E quando sentimos estalarem os alicerces do monumento que ajudámcs a construir, em văo buscamos mante-lo em equilibrio por meio de escoras e de amarras que apenas con.. seguem protelar o inevitável desfecho. Só entăo compreendemos que a catástrofe poderia ser evitada se o nosso apego a s idéias clássicas náo nos tivesse impedido de aproveltar novos elementos oferecidos pela ciencia para a consolidaçăo do embasamento comprometido.

PIZA (1946) descreveu recentemente um caso de soldadura pelas extremidades náo correspondentes de dois cromossomios homólogos do Tityus bahiensis, que serve muito bem para llustrar a inoperáncia da atraçăo ponto-por-ponto na melose. A sold9.dura referida resultou da perda de pequeninos fragmentos centricos de extremidades opastas dos cromossomios, os quais foram encontrados náo pareados na metáfase de um dos espermatócitus jrimários do cisto em que o fenomeno foi observaro. Da fusáo dos dois membros do par resultou um cromossómio complexo de tamanho duplo, provido de um cinetocore em cada extremidade, que se comportava como um monovalente, nåo se orientando e, a avaliar pela sua posiçăo nas célulss cm inmeço de anáfase, passando sem se dividir para um dos espermatócitos secundários. Se a atraçăo ponto-porponto operasse, os dois cromossomios homólogos nele incluidos deviam parear-se tal como acontece nas glandulas salivares dis Lipteros dando origem a uma configuraçăo semelhante a que fol observada por CARSON (1946) no cromossomio X de Sciara impatiens em consequencia de uma inversto subtotal A conrlusăo foi que a soldadura dos dois cromossomios transformou-ns nurra unidade nova, sem correspondente no núcleo, e qua por essa razão se comportava como um auténico monovalerite $O$ náo pareamento das partes do complexo prova a inexistencia de uma atraçáo de pontos. PIZA mostrou numa série de trabaihos (especialmente 1946 b, c) que os cromossomios dos Hemípteros originam-se da soldadura pela extremidade acen. trica das duas metades resultantes da divisáo longitudinal do elementos telocéntricos e que apesar disso esses cromossom so se parear com outros cromossomios, jamais se dobrando para justapnrem as suas duas metades. Isso vem mais uma vez mostrar que $n$ pareamento náo se deve a uma atraça especifica desenvo!vida por gens. O pareamento de "repeats" e de iragnentos cromosiomicos na melose ou nos nucleos somáticos 
(cf. SWANSON 1943) năo permite por enquanto qualquer conclusăo definitiva.

Os cromossomios sáo individualmente distintos. Há nas células soniátịcas dos individuos diplóides dois cromossomios de cada uma das qua!!dades neles representadas. Na melose os cromossorioins da mesma qualidade se unem para formar as pares. O paraamento $e$, por conseginte, especifico. thsse fenomenu tem sito também designado por conjugaça e no entretanto. ninguém, que nos conste, fez, ate agora, qualquer tentativa no sejtido de entende-lo a luz dos modernos ensinamentos coln'dos do estudo da conjugraça dos gametas em geral e de modo musto especial, das recentes pesquisas sobre a conjugaçáo dos Chllsdas.

R.elativamente aos Clliados sabemos de longa data que êsses Protjroários se multiplicam assexuadamente por um processo de lissuraço mediana que se repete inumeras vezes, ap6s - que os individuns resultantes entram em conjugaça, para logo se jepararem e de novo iniciarem sucessivas divisoes. Qs fenomenss nucleares que precedem a fissuraça ou que se realizam por ucasităo da conjugaçăo encontram-se detalhadamente descritos nos tratados de Protozoologia. (REICHENOW 1929, CALIIINS 1926 KUDO 1931, MINCHIN 1922). Num dos casas mais simples, observado em Parameclum, verifica-se que os conjugantes se unem mais ou menos estreitamente pela regia.ventral, fazendo colncidir os citóstomas para a permuta de núclens o macionúcleo de ambos se desintegra sem tomar partc no proresso que se desenvolve. O micronucleo, contràriamente diride-se duas vezes, produzindo quatro pequenos nucleos, trés dos quais desaparecem e o quarto se divide mais uma rez, sendo que um dos produtas dessa terceira divišo passa de ur. animal para o outro e, fundindo-se al com o outro produto da mesma divisăo, dá origem a um sincário do qual văo resultar um novo micronúcleo e um novo macronúcleo. Há, por consszu'nte: uma permuta de partes entre os dois membros do f:ur em conjugaçăo, após a qual os animais se separam para. dentro te algum tempo, entrarem novamente a se multiplicar por via assexuada.

A recente descoberta de SONNEBORN (1937), segundo a qual, no Paramecium aurelia, os individuos pertencentes ap mesmo cione nao se conjugam entre si e quando misturados com ind!viduus de ontros clones podem ou nzo entrar com eles em c injugaçăo, levou-o ao estabelecimento dos tipas de pareamento.

De conformidade com as trabalhas desse autor (1938, 1939, 1939a e 1941), de JENNINGS $(1938,1939,1939$ a) e de outros, as 
espécies de Clllados podem ser divididas em variedades que náo se cnnjugam entre si, sendo que em cada variedade se podem encontrar dois ou mais tipos de pareamento. Tomemos para exemplo uma variedade provida de apenas dois desses tipos, os quais, sob o ponto de vista morfológico, em nada diferem entre si. Designemos esses tipos por A e B respectivamente. Os indivíduos cio tipn a náo se paream entre si, bem como os do tipo B Misturados, o pareamento logo se processa entre os representantes de $\mathbf{A}$ e os representantes de $\mathbf{B}$.

Reunindo-se; dois clones de tipos diferentes a primeira cousa que se observa é a formaçáo de agregados de diversos taman'.ns. Dentrc, em pouco esses agregados se desmancham em pares que nadam livremente. $O$ primeiro contato entre os dois conjugantes se dá por qualquer parte do corpo. Fm seguida eles se mnvimentam um sôbre o outro até se porem na posiçăo adt.quaca, a terindo por uma extensáo maior ou meror da regia. vential e justapondo as bocas para a permuta dos nucleos. bepois de um certo tempo durante o qual os pares nadam livremente, as dcis conjugantes se separam, passando novamente $\therefore$ viver a sua viria individual, multiplicando-se repetidaniente.

Fm algumas espécies, como por exemplo em Euplotes patella (KIMBALL 1939), os pares se formam diretamente, sem uma prévia agregaça.

Esses e sutros estudos relativos à conjugação dos Clliados (literatura em SONNEBORN 1941, JENNINGS 1941, KIMBALL 1943) oferecem-nos a chave que nos haverá de permitir decifrat $u$ enigma do pareamento dos cromossomios na meiose. Vejamos quantas instrutivas analogias se podem encontrar comparanto-re o comportamento dos Ciliados com o dos cromossomios.

Salier:temos em primeiro lugar que os cromossomios vivem livremente no núcleo como os Clliados em uma cultura em cai$x a$ de Petri. Os cromassomios espermatogoniais se multiplicam por fissura.çăo à semelhança dos Clliados. Porém, normalmente, os cromossomios-filhos se separam em celulas distintas, uma situaçăo que se poderia imitar com o Clliados, levando-se r.ara remientes diferentes os produtos de cada divisáo. Depois de um certo numero de divisరes os cromossomios se conjugam. tal cumo se dé coin os Clliados. Num espermatócito antes da melose se er:contram $n$ qualidades de cromossomios (cromossomios heterologos) que se năo paream como acontece com as variedades de Ciliados que se podem encontrar reunidas na mesma ciixa de cultura. Cada qualidade de cromossomio do espermatócito é representada por apenas dois individuos de tipos diferentes (cromossomios homólogos) comparávels, do ponto de 
iistă da fịsiologia da conjugaçăo, aos tipos de pareamento dos Cljiádos. Pór ocrasî́co do pareatiento os cromossómios se agregam

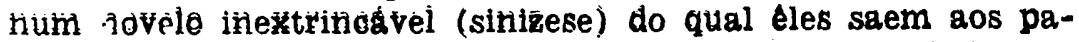
les (paniathemas) e se espalham livremente na cavidade nu. olear (dic:ciñese), tal como vimos acontecer com os Ciliados, que primeiramente se aglomeram para depois se separarem pareados. A senthança do que se passa com os Clliados, também os crunnssóntiot primeiramente estabelecem contato por qualquer nonio do seu corpo para depois ajustarem a sua posiçáo e fazerein coinciair os cinetocores. (Os Ciliados fazem colncidir as bocias). Enquanto se acham pareados, os cromossomios permutam partès (orossing-over) tal como os Ciliados e como estés, logo após sé separam, mutiplicanuo-se dal por diante por simples fissuraçăo. Nas theloses em que nâo há sinizese 0 comportatiento dos cromossomios se compara ao dos Ciliados (Buplotes) que sé conjugam sem previa aglomeraçáo.

Alguitis autores pretendem que as evidencias apontadas em favor de uma atraça dos espermatozbides pelos óvulos nốo såo conoludentes, chegando mesmo a duvidar que um tal fenomeho existk. (Cf. p. ex. WILSON 1925, MORGAN 1927). Todos săo porém, unánimes em reconhecer que o ovulo maduro elímina pela sua superficie substâncias que atuam especificamente 80bre os espermatozóides, ativando-os, aglomerando-os e aglutinando-os. Todos são também acordes em reconhecer que os er permatozóldes reagem prontamente aos produtos de secreção do óvulo e que, diante de certas substâncias empregadas em labosatóric, revelam acentuados fenómenos de quimiotaxismo. (Cf. I.ILLIE 1927, JUST 1939). Por conseguinte, se de um larl. temos orulos que no momento da fertilizaça eliminam sui táncias que agem ativa e prontamente sobre os espermatozo des da mesnia espécie e de outro lado espermatozóides extremamnnte sensiveis e que reagem positivamente à açáo quimio. táxica de certas substán ias, năo se pode descartar a possibilidade da existéncia de uma atração de ordem química do 6vulo soivre i espermatozóide. Foi o que fez InLI: (1939), concluindo, que embora o quimiotaxismo não seja o único fator determinante da aproximaçáo dos gámetas, ele náo pode deixar de influir. $O$ fato de alguns espermatozoides passarem pelas proximidades do ovvulo sem desviarem para ele o seu curso, apont?do como priva da inexistência de uma atraçăo, pode simplesmente significar incapacidade daqueles espermatozóides de reagirem, como outros o fazem, as influencias emanadas d's óvulo. Pode bem ser - e isso me parece, pelo menos em certos cr.sos, muito provável - que açao própriamente atrattva o ovulo só exerça a curta distáncia. Uma açáo multo inten- 
sa dessa natureza, abrangendo um grande raio, teria o inconveniente de arrastar para o ovulo um número excessivo de espermatozóides, o que, além de outras desvantagens, poderia acarretar uma perigosa polispermia. Lutando contra isso, a ação do óvulo consistiria em ativar o movimento dos espermatozódes, alguns dos quais acabariam penetrando na zona de atraçăo, sendo entǎo orientados para a superfície ovular. A produ çáo pelo óvulo de Echinoides de um filamento que se prende : cabeçe do espermatozóide quando êste se encontra ainda uma certa distância de membrana vitelina, na substáncia ge. latínosa que circunda o óvulo, fala a favor de uma açáo de 0 dem quínica guiando o espermatozólde. Penso, concluindo, qur podemos afiimar com CHIARUGI (1929) e outros, existir ur quimiotazismo que conduz os espermatozóides ao contato $i$ óvulo. Alís, trabalhos recentes sôbre os gamónios masculino: e fenininos, ov sejam, andro e ginogamomios, acabaram d nitivamente com as dúvidas a respeito do papel exercido na fecundaçă, pelas substancias químicas elaboradas pelos gametas. (Para detalhes e bibliografia v. BRACHET 1944).

C.om relação à conjugaçăo dos Ciliados, achamo-nos em situaç̣̄o idêntica. Tr.mbém aqui sabe-se com segurança da produção de substancias químicas que agem ativando e aglomerando os indjviduos que se devem parear. Entretanto, também aqui, as op:rióes divergem relativamente à questão da atraçáo. JENNINGS e SONNEBORN, dos seus estudos com o Paramecium, concluiram pela inexisténcia de atração. Esses autores acham que ns Protozoários se encontram ao acaso, separando-se a seguir se forem do mesmo tipo de pareamento ou permanecend unidcs e entrando em conjugação se forem de tipos diferentes. Segundo KIMBALL (1943), cada tipo produziria uma substancia diferente que ficaria à superfície do corpo e promoveria a aderência de um no outro, onde quer que se desse o contato. Do encontro fortuito de dois individuos $d$, mesmo tipo, isto é, providos ta mesma substância, não resultaria nenhuma aderência. $O$ fato de individuas pertencentes ao mesmo tipo de par mento an se encontrarem, nadarem unidos por algum tempo, para tenois se separarem, indica que se pode entender uma uniăc mais duradoura dos individuos de tipos diferentes, sem fazer apsilo a qualquer substância de propriedades adesivas. Quer $n$ encontro se dé entre individuos deste ou daquele tipo, o que ontra primeiramente em jógo é simplesmente a reaça de contat.o. (V. JENNINGS 1942). Como se sabe, is Ciliados reagem 2.0 : $:$ ntato dos corpas sólidos que encontram no meio, procurando entrar com eles em estreita uniáo. Quando dois individuos se tocam, cada um se comporta em presença do outro 
como se fasse um corpúsculo sólido em suspensáo, provocando a reaça te cortato, que por ser reciproca, e mais estreita e duradoura co que a reação unilateral determinada por qualquer outro corpo. Quando os Ciliados amadurecem para a conjugaçáo a reaçăo de contato permanece a mesma entre os individuas do mesmo tipo, transformando-se, porém, numa reação sexual. entre os individuos de tipos diferentes. Essa reaça sexual e, por conseguinte, uma forma de reaça de contato desenvolvidia entre individuos sexualmente maduros e fisiologicamente diferenciados e deve durar todo o tempo necessário para a consumaça do ato que lhes cabe desempenhar. Hho se tratando de uma reaçáo de contato, as conjugantes, uma vez unido: por qualquer parte do corpo, poderzo com facllidade se ajustär na posiçăo mais favorável a troca dos núcleos e se separar uma vez concluido o ato sexual. Isso me parece mais dificil de intender se fizermos intervir qualquer secreçzo com propriedades grudadoras para explicar a permanencia dos corpos em contato durante a conjugaçăo.

A qliastăo da atraçăo é uma questžo à parte. Sabe-se qu? os Cillados secretam substancias que passando para o melo influem. de diversas maneiras sobre os individuos da mesma eispécle que al se encontram, a algumas das quals eles reage:qimiolaxicamente. Sabe-se igualmente que por ocasibo da $c^{-}$ jugaçăo há produçăo de substánclas químicas que póem os individuos $\mathrm{cm}$ grande atividade, promovendo ao mesmo tempo a sua agregaçăo. Temos, pois, os elementos para pensar na existencia de uma atraçáo quimica. verdade que em se tratando de copulaçáo entre individuos livres, extremamente moveis e mu'to sensiveis a diversas sortes de estimulos, a atraçăo entre eles jeve sofrer a influencia de várias causas modificadoras. Parece-me que cada tipo de individuo produz uma substancia diferente com açăo qiumiotática sobre o outro tipo. Essa substancia difunde-se com certa lentidso no melo em que eles es movem ativamente, dando origem a areas de concentraçă diferente que influem nos seus movimentos. A substan. cia produzida por um das tipas adere por algum tempo à superficle cios individios do outro tipo, para ser logo dal lavadr. pela secreçán destes ultimos. $\mathbf{E}$ assim, um individuo do tipo A, ao se sproximar de um individuo do mesmo tipo, cujo corpo esteja envolvido na substancia produzida pelos individuos do tipo B. Junto-se com este. Dado o encontro, prevalece a rear de contato e enquanto isso o individuo se val lavando da substancia qu eo impregnava, o que facilita a separaçăo. Se os tipos que se encontram săo diferentes, entra em j6go a reaçăo sexua: e eles iniciam a conjugaça. Parece-me que a aça da substan. 


$-\ldots, \cdots . .=-\quad-\approx$

cia esvecifica seja apenas a de promover o encontro. Uma vez realizado este, entra a funcionar a reaçăo de contato ou a reaçáo sexual.

Ao examinar culturas de clliados, tive muitas vezes a impresssaso de cue um individuo perseguia o outro a curta distancia, para alcançá-lo ou para se desviar bruscamente da rota. Tambem pareceu-me que ao passarem muito pródmo um do outro os individuos inevitavelmente se encontravam. Há, pois, indicios re atraça. $\mathrm{Em}$ apoio a idéla de uma açăo quimiotáxica, promovendo o encontro dos individuos de tipos diferentes, poderemos citar a observaço de ENGLLMANN com Vorticella. usse autor verfficou mais de uma vez, conforme relata CAIIInSS (1926), desvio de rota e perseguiçăo seguida de uniǩ, que bem atestam influencia de ordem quimica de um individuo sobre outro. Penso, porisso, que poderemos aceitar, com CALrIns, REICCINOW e outros eminentes protozoologistas, a existencia de uri quimiotropismo guiando os Clliados de tipos diferentes para a conjugaçăo

Estamos, por conseguinte, de posse de fundamentos biologicos qu? nos permitem compreender o pareamento dos cromossomir.s. Os cromossomios homologos sta como os Ciliados de tibos diferentes. Paream-se como individuos, segundo os mesmos princíplos que norteiam a copulagaso de gametis ou de células sexualmente diferenciadas. $O$ năo pareamento dos cromossomios na meiose de machos diplóldes de Abrobracon e te outras Fimenópteros cujos machos săo normalmente haplóldas concorda com a explicaçáo acima proposta. O fato de haver em certas plantas pareamento de cromossomios na meiose de ramos estéreis que se tornaram fértels em consequencias de uma duplicaçáo espontanea ou provocada do número de cromossomios e outros semelhantes, nao invalidam a interpre caçăo que dei aos tenomenos de pareamento, porquanto, quer no domisilo cromossomico, quer no dos Cillados, certas condu tas especiais náo puderam ainda ser compreendidas. Assun, casos há em que os cromossomlos, aparentemente normais de individuos riploides, deixam de se parear por razbes que ainda năo foram apuradas. Igualmente, o pareamento dols-a-dols, constant. em individuos tetraplóides nos quais era de se esperar a tormaçáo também de grupos de tres e de quatro, 20 lado de alguns monovalentes, permanece ainda obscuro. Qua:1.to aos Ciliados, a conjugaçăo de individuos pertencentes ao mesmo clone e provenientes do mesmo carionidio, tal coino se tem observado em Paramecium multinucleatum, Paramecium caudatum e até meșmo em Paramecium bursaria (V. referên- 
cias em SONNEBORN 1941), requer novas investigaçరes antes que busquemos encontrar uma explicação satisfatória.

Segundo estabeleceu HARTMANN para a alga Ectocarpus silicosus, as gametas que copulam nơo săo nem machos, nem femeos. num sentido absoluto. Quer dizer que um mesmo gameta pode comportar-se como macho ou como femea em relaçåo a outros, o que, como se sabe hoje, depende das propurçces relativas das substancias (gamonias cis e trans) que cada indivituo é capaz de eliminar. A serualidade passa assim esfera quilitativa para a quantitativa, auxiliando-nos na interpretaçăo dos casos obscuros do comportamento quer de g.גmetas, quer de cromossomios. (Bibliografia em BRACHET 1944).

Qualquer definiçáo que a ciencla procure dar do gen, é evidente que ela pretende apresentá-lo como um elemento or-ganizado e vivo. E como tal esse elemento deve fabricar a sua substancie a custa de substancias diversas do melo celular, as. similando-as e incorporando-as. A principal caracteristica dos corpor vivos é exatamente essa propriedade que so eles tem, de auto-cíntese. O protoplasma, desde que apareceu pela primeira vez na terra, até os nossos dias, parece que se nao modificou no que ele tem de básico. Os seres vivos evoluiram, diferenciaram organelas, complicaram a estrutura, multiplicaram a forma, mas nžo alteraram aquilo que eles possuem de essencial. Da ameba so homem o protoplasma consegulu percorrer millenios de evoluçáo sem perder qualquer de suas propriedades fundamentais provável que o protoplasma tenha, em todos os organisino? a constituiça com que apareceu naquele remoto instante que assinalou o inicio da historia da vida no nosso planeta. As reaçóes em que ele toma parte sabo diferentes daquelas que se operam entre corpos brutos e nessa diferença reside tido a que ele possul de mais importante. Assim, enquanto as corpos jestituidos de vida reagem uns com os outros, para constituirem corpos novos, com propriedades inte. ramente diversas daquelas que caracterizavam cada um deleis antes das reaçCes, 0 protoplasma, ao reagir com a materia bruta, mndifica-a, transformando parte dela em protoplasma que incornora ao já existente e parte em substancias residuais que abandona. A caracteristica dessas reaçóes em que o protoplasma tcma parte é que elas sao unilaterais: as corpos que com ele reagem se transformam, a passo que ele conserva inalterada a sua constituiçăo. Parece que se pode concluir de um grande número de observaçóes, que o protoplasma nto reage diretainente com a materia bruta e sim por intermédio de substancirs que ele e capaz de elaborar. A flsiologia da digestro oferece-nos os elementos para compreender o que se deve 
passar entre o protoplasma e o material do meio com o qual ele tem relaçós: substancias especificas, digamos enzimas, por ele prodvzidas, promovem, umas, a decomposiçáo da matéria bruta, pondo em liberdade os elementos com os quais outras sintetisar a parte a ser incorporada. $\mathbf{E}$ assim o protoplasma cresce. Entretanto, o genetista parece se esquecer desses dadc fundamntais ccntidos na definiçăo de tudo o que é vivo, quan do procura explicar as mutaçóes, ou sejam, as diferenças existentes entre os gens, com base em alteraçóes de ordem química Quer-me partccr que o genetista cal em contradiçăo quando, ir definir o gen, salienta a sua propriedade essencial de auto-elaboração e portanto, de conservação de si mesmo, e, ao compar-: os gens, busca na quimca as diferenças que presume existirem entre èles. Se os gens săo realmente vivos conforme a definiçăo. éles năo devem entrar corporalmente em reaçáo com o melo e portanto nă devem alterar a sua composiçăo quimica. Aceitar que um gen seja capaz de adquirir ou perder determinadas moléculas: ou az̧rupamentos moleculares, entrando por ésse meir na posse de novas propriedades, é o mesmo que identificá-lo com-i matéria bruta, que difere da viva exatamente por essa faculuade. Demais a mais êsse processo, além de constituir uma fonte inesgotável de fáceis mutaçбes, levaria os gens a alteraçōes tão profundas, que deles poderiam fazer os mais variados compostos quimicos. Enquanto uns gens permaneceriam proteings, outros tornar-se-iam hidratos de carbono e outros graxas. Pela perda de uns agrupamentos quimicos e pela aquisição de outros, o gen poderia passar de organico a mineral $c$ até mesmo de molecular a atómico.

As alteraçós que transformam um gen em outro năo devem pois ser de ordem meramente química. Não resta dúvide de que o ser vivo ou mais propriamente, o plotoplasma, possua uma composição química. A vida não passa mesmo de uma aquisiçăo da matéria bruta. A história da evoluçăo do universo nos ensina que a matéria bruta sempre existiu e que a vida um dia se instalou nela como uma propriedade que atè então nenhum corpo havia revelado. Pode-se porisso dizer que a vida é uma propriedade da matéria, que só apareceu quando ela, an jôgo natural das leis que imperam no universo, adquirin uma constituiçăo semelhante a das proteinas e um estado semelhante, ao estado coloidal, organizando-se num sistema fi. sico-quimico que repetidas vezes se modificou e se desintegrou, e que por fim, na hora zero da história da vida, estabilizou-se em consequência de uma faculdade até então inatingida a faculdade de crescer pela incorporaçăo ao sistema já forma- 
do, da matéria sintetisada à custa de substancias do meio extérior

O raciocinio qué vimos sèguindo leva-nós à conclusăo de que a matéria viva, sob o ponto de vista quimico, provavelimente nźo difere em dada da miatéria bruta que hoje con̈hecemo A pronriedade de auto-sintese que a caracteriza e que ela sómente adquiriu depols de haver chegado a una constituigro bastante complexa, pode bem ser uma consequencia de um estado particular, năo dependendo porisso de nenhum elemento especial. Intre uma proteina bruta e uma proteina viva deve táo simente existir uma diferença de estado e assim como falamos em estado coloidal e estado nto coloidal, poderemos falar também em estado vivo e estado. bruto da matéria. A proteina virus de RTANLEY ajuda-nos a compreender essa diferença de estadoc. A passagem direta da materia do estado vivo para o estado bruto é um fenómeno comum aos nossos olhos. A inversa, qua nzó é menos comum, so indiretamente se pode verificar. A converstó da matéria do estado bruto ao vivo só se verifica através da atividade de seres vivos, que, por esse melo, crescem e multiplicam-se. Isso porém náo exclui a possibilidade de ur?a nova transformaçăo direta. Embora as atuais condiçøes físicas e quimicas da terra sejam bem diversas daquelas que vigoravam no remoto instante em que se constituiram as primeiros corpas organicos capazes de servir de substrato a vida, poderiam:s aceitar a possibilidade de novas conversరes de matéria brit:a em viva, considerando que para tal fá năo é mais precisn partir das primeiras combnaçoes do carbono com os metais mais pesados que formavam o núcleo da terra e depois com o vapor dágua da atmosfera. (") O ponto inicial para essa transfcrmaçăo seria hoje representado pelos ultimos elos daquela primitiva série de corpos que terminam nos altos complexas organicas. Substrato para a vida náo mais precisa formar-se, pois que protcinas e seus derivados são de comum ocorrencia na terra dos nossos dias. $O$ que nos parece pouco provável é que os seis que por ventura surgissem hoje como o produto de uma transformaçño direta da matéria bruta fassem capazes de se diferenciar, de evoluir, ou mesmo de se perpetuar naquela for-

(*) Uina exposiç̧̃o bastante clara dos fenómenos que se devem ter desenrola:ic desde que a matéria destinada à formaçăo do nosso globo se destácou $d a$ astrela que se constituiu em sol e nos quais o elemento carbono $d \varepsilon$ sannenhou o principal papel, encontra-se no excelente livro de OPARIN (1988) 
ma primitiva de organizaça. Os seres de outros tempas encortraram uma terra esterilizada que permitiu o seu desenvolv:mento. Nos primeiros dias da evoluçăo os organismos rudimentares que habitavam a terra pouco diferiam entre si e lutavam pela existencia com armas aproximadamente iguais. A terra, desnovoaria, tinha lugar para todos. E como inumeras tentativas devem ter tracassado antes que a matéria conseguisse inaugurar o processo de auto-sintese que assinalou 0 aparesimento da vida, os primeiros seres que se formaram devem tei encontrado abundante material organico para a sua nutriçăo. $A$ compctiçăo deve ter-se iniciado muito mais tarde, quando as águas já pululavam em microorganismos. Atualmente isso năo mals se verifica. Os novas seres que se formarem serăo presais tácels de rere mais evoluldos, já adatados e treinados nos combates da vida. A luta pela existencia acabará com eles no instrnte maimo da sua formaça.

As enzinias indispensávels à vida do protoplasma e por melo das $q^{\circ}$ is elc promove o desdobramento da matéria bruta e a sua transformaça em substancias capazes de serem incorporadas a matória em estado vivo, devem ser produzidas pelo proprio protoplasnia. E como essas enzimas ná devem resultar do desdobramento do substrato quimico do protoplasma, nem tho pouco de rençóes que alterem a sua constitulçăo, segue-se, que, para produzi-las, o protoplasma age apenas como um catalisador, isto é, funciona como se ele proprio fosse uma enzima. A matéria prima com que ele trabalha pertence, pols, ao melo, e năo sua constituiçâ. A auto-sintese nžo sendo possivel sem o concurso de énzimas, temas que o que permitiu a conversáo da matéria bruta em viva fol a propriedade que ela adquiriu de, func! mnando ccmo enzima, jogar com o material do meio no sentido de formar com rapidez novas enzimas necessarias ao desdoibramento de determinadas substancias e a sintese de outras.

Dids a especificidade das enzimas, temos que o que dita a ordem te entrada delas em açăo é a composiçăo química dos corpos que se r.రem em relaçá com o protoplasma. Suponhamos que an jrotoplasma val ter uma nucleoproteina e que nesse protoplasma, além de uma protêase que desdobra aquele complexo em proteina e ácido nucleico, encontram-se mais as seguintes enzemas: uma polinucleotidase que desdobra o ácido nuclêico em nucleotidios, uma nucleotidase que transforma as nucleoticeos em nucleosideos e ácido fosfórico e finalmente uma nuclessidase que decompoe os nucleosideas em bases da purina ou do piramidina a açúcar. Ora, torna-se evidente que nenhu- 
ma dessai ênzimas que atuam sobre o ácido nucleico e seus produtos pode entrar em atividade antes daquela que age èspeciffcamente sobre a nucleoproteina desdobrando-a em proteina e ácido nucleico. Também a nucleosidase năo poderá trabalhar. sein que primeiro a nucleotidase desdobre os nucleotideos a nem esta, por seu turno, antes que a polinucleotídast fragmente a molécula do ácido nucleico. De outro lado, se o que vem ter ao protoplasma é Já um nucleosídeo, claro é, que de todas as enzimas al presentes, só a nucleosidase é chamada à atividade. Em presença do ácido nucleico e dos produtos intermediśrios do seu desdobramento, as diversas enzimas referidas podem agir concomitantemente. Pelo contrário, na ausência desses compostos, nenhuma delas entra em açåo, sem que com isso se oponham a atividade daquelas que se destinam ao desdohramento ou a sintese de outros compostos que tenham por sua vez entrado em contato com o protoplasma. Vemos, pois, qua $o$ que determina a entrada em atividade deste ou daquele produto do protoplasma, o que estabelece a ordem em que cyda um deve intervir e o que marca o início e o fim de sua aiuxção, săo os compostos que vêm ter em contato com êle e os proriutos de suas primeiras transformaçరes.

Zue as enzimas de que o protoplasma se serve para a manutençăo da sua vida sejam um produto de elaboraçáo e que a sua qualidade e a sua atividade aumentem ou diminuam com a presença ou a ausencia das substancias para as quais elas sấ especificas, a fișologia nos dá um grande número de provis. O que năo sabemos, porém, é se na ausencia prolongada de uma dada substancia, a enzima respectiva chegue a desaparerer pur sompleto, ficando o protoplasma apenas com a facullade de elaborá-la de novo, táo depressa a substancia em questão venha outra vez pôr-se em contato com ele. Como no organismo animal a produçáo de certas enzimas é privativa de determinadas células e estas só se diferenciam tardiamente, segue-se que o protoplasma carrega consigo, năo as enzimas pròpriamente. nuas a faculdade de produzi-las nas condiçбes requeridas criadas pela diferenciaçăo. Assim, certas enzimas especifísas to fígado ou do pancreas só se produzem depois que as células hcpaticas ou pancreáticas tenham se diferenciado. $O$ protoplasma, portanto, atravessa uma longa evoluçáo antes que as condiçбes exigidas para uma determinada atividade se realizem no organismo. O mesmo poderiamos dizer relativamente ar.s hormónios. Cada tipo de célula, de conformidade com : sua diferenciaçăo, elabora um determinado hormónio As pr:meiras células de um organismo têm um protoplasma com 
uma soms enorme de potencialidades que mais tarde se objetivarão en: um número restrito de substâncias ativas, de conformidate c:m o rumo que cada célula toma no desenvolvimento. O organismo que se desenvolve, por conseguinte, considerad? como um toro vai progressivamente diferenciando regioes, cada u:na das quais oferece ao protoplasma das células que a constituem um meio propício à consecução desta ou daquela atividade. Sribemos que os hormônios são produzidos por determinados ong̃ãos e por conseguinte, por célụ̣as especializa das e que embora circulem por todo o organismo, só influem sôbre determinadas partes. A diferenciação do organismo no que se refere aos hormónios, conduz, pois, a duas especializaçóes diferentes: uma dá origem às células capazes de elaborar os hormônios e outra às células que, não possuindo essa faculdade, são, porém, as únicas capazes de reagir à presença dêles

De conformidade com uma opinião corrente em genética os gens trabalham no organismo, diretamente ou por intermédio doss seus produtos, como se fôssem ênzimas. Mas como os gens são especificos e só intervêm sôbre determinalas reações, segue-se rue se os corpos que tomam parte nessas reaçōes nắ 'stiverem presentes, êles não poderão agir. A atividıde dos gens depende, por conseguinte, da presença de certas substâncirs.s, isto é, de um certo e determinado meio. A conclisăo a ciilar é, pois, que os gens não entram em atividade sem serem jolicitados e nãc controlam as reaçőes em que tomam parte,sendo, prlo contrário, controlados por elas. Este ponto merece alguma atenção. Admite-se geralmente que os gens contrdam as reaçõas que se processam no organismo. Porém, contruar. uma :eação quer dizer dar-lhe início, imprimir-lhe uma dieção, reg ılar-lhe a velocidade e marcar-lhe o fim. Entretanio, nenhum dêsses papeis se poderá atribuir aos gens se os colsiderarmos corro alementos que funcionam por intermédio ce substâncias de ação catalítica, isto é, de ênzimas. sabido que a: ênzimas não promovem reaçōes, mas apenas aceleram-nas; não regulam a velocidade dessas reaçóes, o que está sob o contrôle imediato de fatores do meio (temperatura, $\mathrm{pH}$, presença ou ausência de certas substâncias, acumulaçăo ou supressāo dos produtos fina.is. etc.); năo lhes imprimem uma direçăo no sentido do desdobramento ou da sintese, pois que isso depende da comp.zsição química das substâncias sôbre as quais vão agir c portanto, tambéin. da permanência no meio ou da retirada, dêste ou: daquele produto das reações; e finalmente, não suspendem as ręçóe o que automáticamente se dá quando o 
desdobramento ou a sintese se completa. claro que o genetista so aft ma: que o gen age como enzima e controla as reaçరes, comete uma nova contradiçăo, pois se o gen funciona como enzima, ele năo exerce controle algum sobre os fenomenos em que intervém. Dessa contradiçáo se poderá sair com facilidade aceitando-se que de fato o gen funcione como enzima, sindo como tal controlado pelos agentes do meio. Aquela contradiçāo, aliás, só resulta de uma opiniăo preformada, segundo a qual cs gens, como entidades permanentes, determinam e controlam os processos que fazem de um ovo um organisms.

Ninguém sabe como os gens trabalham. Apenas se fazem conjeturas. Uma cousa, porém, podemos tomar como certa. que os gens, qualquer que seja o concelto que deles façamos, náo sáo nada mais, nada menos, que protoplasma. Sendo protoplasma eles năo săo nem enzimas nem hormonios, embora possam produzir substancias com funçăo quer de enzimas, quer de hormónios. E como nas células o protoplasma se diferencicu em organelas especializadas com as quais o trabalho fol dipidico, segue-se que onde quer que se localize a funçáo genici, ela. só poderá se exercer com o concurso de outros elementes resultantes da divisăo do trabalho. Assim sendo, se atribuirmos aos gens a faculdade de produzir substancias com propriedades de enzimas, năo podemos fugir à admissăo da colaboraçêo de outras partes da célula. O gen, para produzir uma substancia ativs deve funcionar como um plastidio ou qualquer outro organólde. verdade que quanto mais nos aprofundamos na anál:se dos fenomenos vitais, mais embaraçosa se torna a nassa situação e ros perdemos facllmente na complexidade dos fatores que entram em jogo. lógico que um plastidio ou um gen $a 0$ efetuar o seu trabalho, necessita de matéria prima. Fssr matéria prima năo é a substancia fundamental que os cor.stitui. quer dizer, nzo é protoplasma e sim produto de sua atividadc. Por conseguinte, se alguns dos outros colaboradores năo funcionar, nem o plastidio nem o gen, poderá concluir qua!quer atividade. Por mais simples que pareça ser um elemento, se o trabalho depender dele, para o resultado final ele será tåo importante como os mais complexos membros do sisteria

O clioplasma e indispensável a vida da célula. A sua atividace no metabolismo e portanto na preparaçáo do material com que trabalham os diferentes organoides é fora de qualquer dúvida. Osi gens nada fariam sem o seu concurso. Intretanto noo podemos determinar a parte que lhe cabe nos feno- 
menos hereditários, simplesmente por ser ele um complexo indissociável e aparentemente homogêneo. Afora os casos em que poder ${ }_{\perp}$ os reconhecer nêle a presença de elementos figurados de valor morfogênico sôbre os quais podemos agir, nada mais existc que pnssa raceber um tratamento experimental. Com os gens nãn se dá o mesmo. Estando êles localizados em estruturas reconheciveis e que podem ser removidas ou transferidas para rutros organismos, foi possivel constatar a necessidade da sua presença para a produçăo de determinados caracteres. Da verifịação da que um caráter não aparece na ausência de cer.to gen, não se pode concluir que o gen seja o determinante especifico do caráter. Ele é um simples colaborador. Pode até acontecer que a sua contribuição, comparativamente, seja insignifjcante. Sendo, porém, essencial, para o prosseguimento da série de reações que preparam o caráter, em chegando 0 momento de sua intervençáo e năo se achando êle presente, a cadela se interrompe, os fenómenos tomam outro curso e o caráter esperado não se manifesta ou se modifica. Uma mutação. por səu turno, pode se dar em qualquer dos membros de um. sisteria coortenado. Suponha-se que a mutação se operou no gen, continuando na mesma os outros orgăos do sistema. As reaçôes dar-se-ão como de ordinário até o momento da entria.. da do gen em atividade. Daí para diante os resultados se alteram porque a contribuiçăo do elemento mutado tornou-se diferente da costumeira. Mas se a mutaçăo se der num outro órgão o lesuitado será igualmente diverso do habitual. A partir do momento em que o órgão mutado entra em açáo as reaçôes no sistema começam a tomar um novo rumo e quando o gen vier a cooperar já encontrará o sistema alterado. O comportamento das mutações não gênicas, pela natureza do seu subst‘ato, não se pode estudar, embora possam também elas dissocial-se como acontece com as gênicas. Porém, é claro, que se o caráter mutado for mendelizável, jamais ocorrerá ao genetista que este possa ter tido por origem alterações no funcionamentn de órgăos năo cromossómicos do sistema.

$O$ genetista, embora aceitando que o gen trabalhe segundo o meio, pensa ser êle, o gen, o controlador do meio e o determinador do caráter. Esquece-se por conseguinte que trabalhar segurito um meio é fazer o que o meio permite, é ser controlado pelo meio. Entretanto, essa idéia de que o gen só entra em aça se o meio estiver preparado para isso, leva-nos à suposição de qu:e 0 gen. em tôdas as partes do organismo onde o caráter em que êle intervém (ou que elé determina, na ilinguágem da genética) não se manifesta, permanece em estado de espera, 
isto é, em inatividade. Isso quer dizer, em linguagem objetiva, que o: gens que devem caracterizar os pelos do animal, nada têm que fazer nos órgăos internos ou nas partes externas destituidas de pelos. $\mathbf{E}$ como há gens que só trabalham em áreas extremamente resuritas do organismo, chegariamos, por essa via, a resultados bastante estravagantes. Parece, porém, que êsse racionínlo ultra simplista e inteiramente incompativel com a complexidade dos fenomenos biológicos năo deve prevalecer. O gen năo tem momentos de inatividade; ele nunca aguarda uma opcrtunidade para entrar em açăo. Todas as oportunidades são a sua oportunidade. Trabalha sempre, ininterruptamente: onde quer que se encontre. Dal a conclusao de que todos os ger:s conperam para a produção de todos os caracteres. BRINK (1929), no seu estudo sôbre a fisiologia do gen "waxy" do mllho, escreve

'It might reasonably be supposed that the genes call forth a consecutive series of reactions, each reaction providing the necessary physiological basis for the succoding one Each gene becomes functional when its approprlate substratum emerges in response to the activities of genes already in play. The phenotipic effects show that there is wide diversity in the propertles of the individual hered!.tary elements and it is a logical inference that each gene requires certain specific intra-organic environmental conditions in order to function. If this be granted it follows that the genes will come into action in orderly sequence. While the genes are the same in every cell they will function in a everchanging way as they alter the circunstarres under which they operate. According to this hypothr.sis each gene comes into play upon the complection of certain earlier events primarily controlled by other genes. Fach factor may not be physiologically active at all stages. Some genes may be narrowely restricted in their operation; uthers may function over a wide range of ontogenetic conditions. At one stage in development a particular gene may act in one way and at another stage in a different manner because the milieu has at been changed in the interval.". (Pag. 521).

E pouro além :

"The suggestion that the genes, sough remaining the same in every cell, may neverthelees govern differentia- 
t: on by series of chain reactions, each reaction changing the substract upon wich the gene complex impinges, which, in turn, opens the way for further physiological events. w!ll strike the chemist and the physiologist with a familiar ring." (Pag. 522).

Pelo que vemos no pequeno trecho acima transcrito e que correspunde a uma opiniáo geralmente aceita em genética, o gen pods ser considerado como desempenhando dois papeis no organismo: um determinando o caráter que lhe é atribuido e outro preparando o melo para que outros gens possam determinar outros caracteres. A primeira vista parece que somente o primeirc papel é especifico. Mas, pensando bem, veremos que êsse papel especifico só se exerce em um certo e determinado melo preparado pelos demais gens e que, por conseguinte, a açăo co meio na determinação do caráter é tão específica quanto a açáo do próprio gen a que o caráter é atribuido. E como em qualquer momento da história do organismo um gen especifico trabalha em um melo igualmente especifico, segue-sr: que o trabalho dos gens que preparam o melo é também especifico. A atividade do gen, pois, quer na determinação do caráter, quer na preparação do meio, é sempre específica. De fato, se uma chave é especifica no sentido de ser a única capaz de abrir certa porta, a porta năo deixa de ser igualmente especifica no sentido de só se delxar abrir por aque.la chave. $\mathbf{E}$ assim todos os gens têm a mesma responsabilidade na caracterizaçáo đo organismo, trabalhando todos, ativamente, em todos os momentos da sua historia. A idéia de que um g€n aguarda em inatividade o momento de entrar em ação, isto $e^{e}$, espera que os outros gens the preparem um meio especifico, năo deve, pols, prevalecer, porquanto o meio é semp". especifico para a atuaçáo de todos os gens e todos os gens trabalha:n ao mesmo tempo na preparaçáo de todos os meios. Os gens est esperam por um meio adequado ao desenvolvimnto de determinaria função Mas isso nåo significa que éles permaneçam em repouso enquanto esperam. Eles nunca repousam Enquanto aguardam certas circunstancias, trabalham nas circunstâncias prévias tes passam de meio a meio, de atividade a atividade, sim parar em parte alguma.

T'emos entăo, conforme dissemos um pouco acima, que todos os gens stán igualmente responsáveis por todos os caracte. res, nšo se podendo atribuir a nenhum dêles aquela açáo espe. cifica imediata sóbre um determinado caráter. Se alguma es- 
pecifinidade exjstir, essa so podera ser aquela que se refere au modo único de cada gen colaborar com todos os outros numa determinada parte e num determinado momento da historia do organismo. Nessas condiçóes nzo seria passivel eleger um determinado gen como o autor de determinado caráter. Caráter é o resultado final e visível de uma série de fenomenos inteiramente desconhecidos, que se pode representar por um simbolo. Assim, poderfamos designar por $\mathbf{V}$ as acontecimentos que se desenrolam no organismo de uma mosca a partir da entrada do ovo em desenvolvimento e acabam pela produçăo dc um individuo adulto exibindo olhos vermelhos. F representeria portanto o resultado da atividade de todo um organismo o genetista, porém, baseado em teorias que ele presume bem fundamentadas, transfere para um determinado gen o simbolo que deveria exprimir, conjuntamente com outras, as atividades de todos os elementos do genótipo. O resultado aparente será o mesmo. O real, entretanto, poderá ser fundamentalmente outro e revelar a arbitrariedade do conceito do gen. Suponhainos um inseto de olhos vermelhos que se cria no la.. boratório. Asse inseto dá origem a uma mutaçáo eosina que se comporta de conformidade com as leis mendelianas. Bmbora năo se tcnhe. alnda localizado o gen original e o mutado, năo resta dúvida: em face do seu comportamento nas experiencias de cruzamentrs, que eles sejam aleles, isto é, que um seja mesmn o resultado de uma mutaçăo do outro e que portanto ocupen a mesma posiçăo em dois dos cromossomios homólogos da guarniç̧̌̃o do inseto. Chamemos de $\mathbf{V}$ a gen original. Encontram-se com êle no mesmo cromossomio, mais os gens $\mathbf{X}, \mathbf{Y}$ e $\mathbf{Z}$. O cromossomio original, de acordo com a genética, seria XYZV, an passo que o cromosscmio mutado seria XYZV'. A mutaçăo de $\mathbf{V}$ para $\mathbf{V}$ teria transformado o olho vermelho em ollho eosina. Aceitando, para fins de discussăo, que exista de fato um sen $\mathbf{V}$ responsável pelo olho vermelho do inseto, pergunta-se se o olho eosina seria realmente o produto de uma mutarăo daquele gen. O genetista diante dos resultados de cruzamentos responderá. sem pestanejar, que sim. Eu, porém, retrucarel, gue pode ser que sim, mas também pode ser que n\$̊ E argumentarel segundo o raciocínio da própria genética : c gen $V$ produz o olho vermelho no ambiente que the prepararam os outros gens. Portanto V esta agindo no meio resultante ds interaçăo de XYZ com todos os outros gens. Se as gens trabalham diferentemente de conformidade com 0 melo (Cf BRINCK, pag. 522) teremos que, se qualquer deles mutar, o moic se altera e consequentemente 0 carater resultante do trabalhc 
de um gen particular. Se os gens entram em atividade na ordem XYZV e $\approx$ mutaçáo se verificar, digamos, em $\mathbf{X}$, que pasrará a $X^{\prime}$ a reaçáo de $\mathbf{Y}$ mudará e bem assim a de $\mathbf{Z}$. $O$ resultado é que quando $\mathbf{V}$ entrar em atividade o meio ( $\left.\mathbf{M}^{\prime}\right)$ será bem diferante daquele original (M) e nesse novo ambiente ele produzira um olho eosina em lugar do olho vermelho. $O$ resultado globql é o mesmo e o simbolismo genético poderá continuar a representá-lo por $V^{\prime}$ como se ele fosse devido a uma mutaçăo de v. A realidade blologica porém, pode ser, como vimos, bem outra.

O genetista reconhece situaçбes em que o resultado esperado năo aparece. Com o fim de esclarece-las apela para a intervenḉco de nlitros gens (modificadores, supressores, ativadores, intensificadores, diluidores, aceleradores e tantos outros) e com isso nada mais faz do que deslocar o problema. Vai criando novas e novas entidades, que cada vez mais complicam a situação. E para que o sistema passa funcionar atribul a entidades hipotéticas faculdades verdadeiramente miraculosas e sem paralelo em tóda a biologia. Afirmar, como a genética o faz com tanta simplicidsie, que o gen fabrica uma antocianina, uma enzima ou u!n hormonio, é atribuir-lhe funçoes que sómente estruturas ruit? complicadas seriam capazes de desempenhar. Semethantes atividades săo atributas de células e nơo de gens e segunto se depreende do importante trabalho de BOWEN (1929) ao citoplasma cabe a parte especifica do fenomeno de elaborafắo. Aliás, conforme se sabe hoje, o núcleo passou para um plano secundário, năo sendo o principal formador e nem o de. positário das enzimas que trabalham na célula, como antes se acreditava. (Cf. BRACHET 1944). O genetista procura sair dessa dificuldade dizendo que cada gen trabalha de colaboraça com todos os outros e com o citoplasma. Mas isso entro signitica que o que trabalha de cada vez é a célula tóda e náo - ger: $\mathbf{E}$ se é a célula toda que trabalha, quer dizer que todos os geris estấo em atividade em todos os momentas da vida do organismo e que por conseguinte a atividade deles muda conforme a parte do corpo que a célula deve formar, uma poss bllidade fá reconhecida por alguns autores. (MORGAN 1921. 1934, STERNE 1936). Nessas condiçరes desaparece a diferença especifica entre as gens, já náo se devendo falar em gens de olhos, de antenas, de patas, de asas, de coloraçáo, ou seja lá do que for. A questáo fica assim muito simplificada, livrando a genética da assunçáo inaceitável, que muitos ainda fazem, segundo a qual, enquanto certas gens trabalham em determinadas partes do corpo, outros ficam al inativos. 
Aiguns trabalhos interessantes de embriologia experimental mostram claramente que certos caracteres considerados pela genetina como sendo produzidos por um único par de gens com atuaço localizada em determinados orghos, se devem, na realidade, ao mau desempenho de funçbes que interessam $a$ economia geral do organismo e que porisso podem repercutir de maneira caracteristica em diversos órgăos, sem que nesses orglos haja qualquer gen operando de modo especlfico. $\mathbf{t}$, por exemplo, o caso do gen "creeper" da galinha.

Trata-se, como se sabe, de um gen dominante Cp, letal em homozlgose (CpCp) e produzindo, quando em heterozigose (Cpcp), uma sérte de graves malformaçoes interessando principaltiente as asas, as patas e os olhos. Nestes últimos o gen em questro. além de outras, determina uma anomalia conhecida por "coloboma", devida ao fato da fissura coroidiana năo se fechar, em consequencia do que a retina, dobrando-se sóbre os bordos ta abertura, forma uma duplicaçô que avança por uma extensấo maior ou menor da área que no olho normal deveria ser ocupada pela coróide.

A genética classifica o gen "creeper" como sendo um gen pleitrópico, isto é, um gen com atuaçăo localizada em diferentes partes do organismo (asas, patas, olhos), produzindo em cada umi dessas partes, uma anomalia caracteristica. Assim. o colobama seria o resultado da atuaçăo do gen $\mathbf{O p}$ nos tecidos do ollho. Entretanto, os trabalhos de HAMBURGER (1942) e de GAYFR e HAMBURGER (1943) oferecem-nos elementos que permitem concluir que as modificaçzes operadas no olho da zalinha ño podem ser atribuidas a uma atuaçáo local de gens De fato aquêles autores fizeram uma série de transplantaçóes ortoth́picas de primórdios de ollho de diferentes constituiçóes genotípicas. Assim, tecidos embrionários destinados a produzir o olho te im organismo normal (cpcp) foram implastados na regián correspondente de um embrião homozigoto para o gen "cree.jer" (CpCp). O resultado fol o aparecimento de um olho colobomatoso e a conclusăn é que o caráter coloboma năo se deve a ação local de gen's especificos nos tecidos formadores do olho, porquanto êsses tecidos provierem de um organismc normal em que o gen "creeper" não existia. A transferencia de um primbrdio ocular de um embriáo homozigoto para o gen "creeper" para um embrião desprovido daquele gen, deu lim resultido a meu ver ainda mais interessante, porquanto mostrou que năo obstante presente em dose dupla, um gen de efeltos täo Arásticos mesmo quando em doses simples (Cpcp), fo incapaz de produzir o coloboma num organismo de constitui. 
ção normal. Fica pois mais uma vez comprovado que o caráter coloboma náo se deve à atuação no ôlho de gens especificos $e$ sim è a consequência de uma condiçăo muito mais geral @ :emota zue modifica o desenrolar habitual dos fenômenos de deseinvolvimento.

Diante dêsses resultados o caminho a seguir pela genética para pór os seus dados em acórdo com os dados da embriologia experimental, seria modificar o conceito de gen pleiotrópico. O pleiotropismo poderia por exemplo ser aplicado so aos efeitos e năo às causas. Um gen pleiotrópico seria aquêle que, à seniolhança dos demais gens, atuaria de maneira especifica modificando estruturas fundamentais das quais dependeria o desenvolvimento ulterior de outras partes do organismo. E dêsse moro uma única intervençăo oportuna do gen poderia exercer uraa influência secundária capaz de modificar de maneira mais ou menos profunda e variada diferentes caracteres do organismo. Entretanto, essa nova definiçર̃.o de gen pleiotrópico não suprimiria a idéia de ação localizada. Apenas a recuaria para uma estrutura mais primitiva de um estado menos avançado do organismo em desenvolvimento. Aliás, conforme afirma HAMPURGER (1942), o coméço lógico de uma pesquisa sôbre o modo de ação do gen do ponto de vista embriológico está em se procurar acompanhar a modificação estrutural condicionada pelo gen, até o ponto em que ela primeiro desvia visivelmente do curso normal do desenvolvimento.

Os múltiplos efeitos do gen "creeper" na galinha são devidos a uma perturbaçáo geral do desenvolvimento do embriáo em crnsequência de uma deficiente nutrição dos tecidos resultarte de notável anomalia circulatória. De posse désses conhecimento CAIRNS (1941) conseguiu reproduzir em individuos normais as malformaçరes atribuidas ao gen "creeper", interrompendo experimentalmente as comunicaçбes vasculares entre o corpo do embriáo e o saco vitelino. Isso mostra que bastaria uma única intervençăo genica no sistema vascular do organismo pira produzir por meios indiretos os conhecidos efeitos nos olhos, nas asas e em outras partes do corpo. evidente que o ger deve intervir em tempo de desviar o curso normal do deservolvimento do aparelho circulatório, atuando quer no corpo do embriáo, quer nas paredes do saco vitelino. Porém, a partir de um certo limite além do qual seria tarde demais para agir, êle poderia entrar em ação cada vez mais prematuramente, impedindo a anastomose dos capilares vitelinos ou reduzindo o seu número, suprimindo algumas ilhotas sanguineas da mesodierme no embriáo de poucas horas de incubaçáo, como até 
mesmo p^deria agir no disco germinativo antes da gastrulaçăo. Mas. se a genética abrir măo do efeito direto do gen na parte do corpo em que o caráter se manifesta (asa, pata, olho), ela terá de ir recuando de órgão em orgáo, de tecido $\mathrm{em}$ tecido, d? célula em célula, até atingir o óvo - ponto de partida de tódas as atividactes que promovem a diferenciação do organismo e a caracterizaçăo de tôdas as suas partes. De fato, se o gen que interrompe luma nervura da asa de um Díptero năo atua na nervura e sim na asa que se desenvolve, poderemos recuar sem inconveniente a sua açáo para o esbóço do disco imaginal da asa, ou para uma determinada célula da blastoderme que dá origem ao esboço, ou para a regiáo do blastema que se converteu na célula em questáo, ou, o que é o mesmo, para uma determinada áres do citoplasma ovular. Quando a genética fizer esse recun do caráter ao ovo ela terá na realidade feito um extraordinário avanço. Ela se terá pósto de pleno acórdo com a embriologia e com a fisiologia, terá abandonado uma dialética cheia de contradiçóes que nada tem conseguido no sentido de uma verdadeira explicação dos seus fatos e se identificará com a biologia, da qual muitas de suas hipóteses a tem divorciado.

ur fato $_{2}$ conhecido de longa data, que submetendo-se um organismu normal à açăo oportuna de agentes adequados, se consegue reprocuzir um grande número de formas inteiramente comparávels às produzidas naturalmente pela atuaçăo de gens bem conhecidos. Destes agentes o calor ocupa o primeiro lugar. Já em 1896 STANDFUSS mostrara que pela aplicaçăo de temperatiras extremas às crisálidas de Lepidópteros obtinhamse cónias bem caracterizadas de várias raças geográficas desses inset2s. Fimbora a literatura registre de quando em vez alguns casos da mesma natureza em diferentes animais, fol somente com a utilizaçấn da Drosophila que o problema póde receber o trata:nerto que merecia. A essas reproduçôes năo gênicas de caracteres condicionados por gens deu GOLDSCHMIDT o nome de fenocóplas. (Para detalhes e literatura cf. GOLDSCHMIDT 1938). Esse autor, que foi, sem dúvida, o primeiro a dilatar e aprofundar as pesquisas nêsse campo, resume do seguinte modo o resultado dos seus trabalhos:

Submetendo-se larvas de Drosophila de determinada idade a temperaturas variando de 35 a $37 \mathrm{gr}$. C., as moscas resultantes extbem um grande número de variaçбes somáticas a dentre estas numerosas fenocópias de conhecidas mutaçбes. Pràticamente aparecem cópias de quase todas as mutaçoes dos pelos, das asas e dos olhos, e bem assim, de algumas muta- 
çбes da forma do corpo e dos apendices. Muitas fenocópias constituem uma série correspondente à formada pelos alelos múltiplos já conhecidos, bem como às que se poderiam esperar de certos gens dos quais năo se descobriram ainda as formas alélicas. Conforme mostrou GOLDSCHMIDT, o que aliás era de se supor, os resultados obtidos dependem do grau da temperatura aplicada, da duraçăo da aplicação, da constituiçăo genética do individuo e do estado do desenvolvimento em que ele si encortra no momento de ser submetido a experiencia. De todos êsses pontos, o que me parece mais interessante é o ultimo, isto é. o estado do desenvolvimento do organismo por ocasião do tratamento.

Ficou estabelecido que para produzir o seu efeito o agente deve atuar durante um determinado perfodo da vida do organismo ein formaçáo, fora do qual o organismo deixa de reagir de maneira apreciável. asse periodo no qual o organismo se mostra sensivel as influencias modificadoras, reagindo de maneira mais ou menos pronunciada de conformidade com as circunstancias, foi chamado periodo sensível ou crítico. Náo so a duração do período crítico varia, como também a sua localizaçăo relativamente ao tipo de fenocópia a ser produzido. Isto quer aizer, em 'uutras palavras, que o organismo pode, por exemplo, se mostrar sensivel num período muito limitado de sua vida larváila ou num perído mais extenso e que esse período pode se achar mais próximo ou mais afastado do término do estád'c larvnl. Assim, enquanto as fenocópias correspondentes a mutaçăo "scalloped" só se conseguem fazendo a temperatura agir num perído muito próximo da pupaçáo, as fenocópia: correspondentes as asas vestigiais e aos olhos "barra" tem um perioclo critico mais amplo e mais afastado do estádio pupal. Em muitos casos conseguiu-se evidenciar a coincidencia que existe entre o período crítico e o desenvolvimento de estruturas larvárias responsáveis pela formaçăo dos orgăos que aparecem. modificados no adulto. Por exemplo, o periodo critico para as alteraçбes que reduzem o número das facetas oculares vai do instante em que os discos imaginais dos olhas começam a se separar dos discos antenais até o início da diferenciaçáo das facetas.

GOLDSCHMIDT, estudando os efeitos da temperatura na produçă das fenocópias e comparando-os com os produzidos pelos gens correspondentes chegou a interessantes conclusరes a respeito do modo de ação déstes últimos. Os gens agiriam no organismo à semelhança da temperatura, modificando a velocidade dus processos ou simplesmente das reaçóes que nêle se 
deservoljem. Porém, acompanhar GOLDSCHMIDT nesse terreno sm que ele baseou a sua importante teoria, exigiria rever tôda a volumosa obra daquele autor, o que nåo cabe nos limites deste pequeno trabalho. (Cf. PIZA 1944).

Os fatos relativos às fenocópias, de alta significaçăo geral, săo muitว expressivos sob dois aspectos particulares : mostram de maneira bastante clara e irretorquível que as particularidades morfologicas que caracterizam os seres podem ser produzidas por fatores năo genicos e que a açáo modificadora do caráter nžo atua diretamente na parte do corpo que o exdbe $e$ sim num rsbóco ou primórdio já determinado, porém ainda lábil ou năo conformado, que só mais tarde irá se desenvolver.

Com relaçăo ao primeiro ponto, queremos assinalar, que à parte a questác da hereditariedade, que constitui outro problema, a mrrfogênese em si, ou seja. a elaboraçáo de uma forma diferente da forma inicial, năo é atributo de gens especificos e sim uma conseguencla de alteraçóes na marcha geral dos. fe-. nomenos que se desenrolam no organismo todo. Havendo mais de um fator produzindo o mesmo efeito (gens, temperaturas, raios $X$, etc.), a especificidade evidentemente desaparece.

De todos os fatores capazes de produzir uma determinada forma, o que opera no organismo nas condiçбes normais da vida é o gen. Mas por gen, na minha opinião, se deve entender todo o si.jtema que se constitui no momento em que o espermatozoide penetra no óvulo para fertilizá-lo, pois dele depende a forma final do organismo. Esse sistema chama-se ovo. Uma mosca do asas normais seria aquela que tivesse para ponto de partida um sistema-ovo que poderemos chamar de "normal" :om relaçăo ás asas Uma mosca de asas vestigiais seria, por seu turno, aquela, cujo desenvolvimento partisse de um sistema-ovo "vestigial". Em qualquer dos casos o caráter considerado dependeria da constituiçăo e do funcionamento do sistema inicial. O sistema-ovo, como qualquer outro sistema, é integrado por um certo número de órgáos, que trabalham desde - infcio na mais franca colaboraçăo. (Citoplasma, condriossômios, cro:nossômios, plasmossómios, etc.) Quase nada sabemos a respeitu do modo de açăo de cada orgăo e multo menos de suas relaçóes funcionais. Quando, em consequencia da especializaçăo e da divisăo do trabalho, um determinado orgão está exercenco uma certa atividade, ignoramos quais os outros orgáos de que aquele mais depende para a consecuçăo imediata do papel que num dado momento the cabe desempenhar. $O$ que podemos de ante-mão afirmar é que sỏzinho, isto é, sem o concurso de outros elementos do sistema, ele nada poderá fazer. 
nominam orgåos vitais. Orgãos muito especializados, destinados ao desenipenho de funçбes que năo sejam vitais, para trabalhar ou se couservar em condições de poderem fazé-lo, dependem, em primeiro lugar, dos órgåos vitais e em segundo, de outros orgãos que com eles colaboram diretamente. Entretanto, o sistema pnde ser privado dos órgãos náo vitais, conservando-se em vida a despeito de nắ mais ser capaz de desempenhar o papel que de modo especial estava confiado àqueles órgáos. Quanto mais simples for o sistema, mais estreita será a dependencia dos seus órgãos. Assim. um sistema constituido por dois órgãos apenas - e êsse seria o mais simples de todos os sistemas não poderá evidentemente privar-se de qualquer deles. Cada órgáo do sistema pode por sua vez constituir um sistema menor. A célula, por exemplo, seria um sistema de dois órgáos, o citoplisma e o núcleo, cada um dos quais constitul um ristema menor. Sistemas, pois, se integram, para formar sistemas cada vez mais complexos. Os sistemas integrantes constituem os órgăos e o sistema integrado o organismo. Entretanto, para que um sistema seja considerado organismo é preciso que ele possa viver independentemente. Assim, uma célula vivendo independentemente na natureza é um organismo, integrada no orgarismo passa a ser apenas um órgáo.

Com isso eu quis afirmar que tudo o que se passa no organismo \& obrэ do organismo todo. Os órgăos săo apenas os instrumertos por meio dos quais o organismo desempenha as suas fur.çōes. As funçశ̃es, num sentido largo, săo, pols, do organis'no e não dos órgãos. Os dentes năo mastigam; é o organismo que mastiga por melo dos dentes. Os pulmós náo respiram; é o organismo que respira com o auxilio dos pulmões. $O$ intestinos năo digerem e nem absorvem os produtos da digestão; é o organismo que o faz por intermédio daqueles órgáos. Seguindo a mesma órdem de idélas teremos que as chamadas funções gênicas da genética clássica năo pertencem a órgăos especiais - os gens, e sim ao organismo todo. Os caracteres a éles atribuidos săo na verdade produzidos pelo organismo fun. cionandc como um todo.

Muitos genetistas, seguindo a teoria de GOLDSCHMITD do modo de ação dos gens, pensam, como já disse, que cada gen espera o momento oportuno de entrar em atividade, o que so consegue quando os outros gens lhe tenham preparado o melo para isso. Portanto, se o gen tem um momento de entrada em ação, quer dizer que antes désse momento ser alcançado éle se acha em espectativa, isto é, em inatividade. (Cf. PIZA 1941). 
Para substituir esse ponto de vista, a meu ver inaceitável, poderemos adotar um outro, muito mais logico e em plena harmonia com os fatos năo só da genétíca, mas de tóda a biologia e bem assim, de acordo com os principios básicos em que essas ciências :e fundamentam. Esse novo ponto de vista consistiria em reconhecer, conforme mostrel em páginas anteriores, que todns os gens trabalham ao mesmo tempo em colaboração com ns outros elementos da célula e que esse trabalho de conjunto modifica-se com 0 desenvolvimento nas diferentes partes do organismio. Essa maneira de encarar a questáo é-nos imposta pelo exame dos resultados cada vez mais numerosos de investigaçōes nc campo da embriologia experimental e se nos apresanta como a única que no momento nos parece capaz de tirar a genétice do artificialismo perigoso para o qual a compele vertiginosamente a teoria do gen corpuscular. Fundadores e construtores da genética clássica, haviam já vislumbrado - caminho que acabo de apontar, assumindo, porém, uma atitude de espect?tiva. (MORGAN 1924, 1934, STERN 1936, v. também comentário em PIZA 1941). O momento é, porém, chegado, de tomarmos decisivamente por essa via, nova e ampla, que nos conduzirá a uma compreensão bem mais biologica dos fenomenos ie hereditariedade.

im raciocínio muito simples val mostrar-nos que os gens devem de fato trabalhar diferentemente nas diversas partes do organismo em formaça. Tomemos primeiramente como premissas necessárias a compreensáo do assunto, alguns fatos, que por constituirem verdadeiros axiomas da biologia, nâo exigem demonstrıçăo. Por exemplo : Uma célula nervosa é diferente de uma célula muscular e isso devido ao fato de cada uma delas ter seguido um rumo diverso na diferenciaçăo. Aa se diferenciarem numa ou noutra direçåo as células se modificaram como sicternas, isto é, tódas as suas partes se alteraram. 0 núcleo da célula nervosa é por conseguinte diferente do nicleo da célula muscular. Essa diferença năo é uma simples diferença de forma; é também uma diferença de funçăo e esta existiria mesmo que se náo pudesse descobrir as divergencias estruturais. Aliás, em muitos casos em que uma divergencia real existe, quer entre células ou partes de células, quer entre organismos, nenhuma particularidade estrutural se pode encontrar responsabilizável por aquela divergencia. Essa seria entáo uma divergencia funcional, isto é, fisiologica. E desde que as funçōes sejam diferentes os órgáos responsáveis devem também sê-lo a despeito da nossa incapacidade em descobri-lo. Assim, os Ciliados da mesma espécie, pertencentes a variedades que 
se nåo conjuguem, são diferentes embora năo possamos descobrir onde resida essa diferença; os cromossómios năo homologos de um individuo qualquer sáo diferentes apesar de se apresentarem, como frequentemente acontece, com as mesmas dimensñes e as mesmas formas; o sangue humano, qualquer que seja o seu tipo, năo acusa nenhuma particularidade estrutural que permita distingui-lo do sangue de outros tipos, a despeito de conhenidas diferenças.

Ao compar:irmos órgáos. ou individuos devemos, pois, estabelecer uma distinçăo entre forma, estrutura e constituiçăo. A forma e a estrutura podem ser diretamente apreciadas, ao passo que a constituição só o poderá por meios indiretos, ou seja, pela tunção. Da mesma forma, estrutura e constituiçăo seriam por exemplo os órgáos correspondentes de dois individuos do mesmo clone ou nascidos da poliembrionia. Da mesma forma e estrutura, porém de constituiçăo diferente, seriam os órgãos correspondentes de individuos pertencentes a espécles distintas. As glândulas mamárias da égua e da asna, as glandulas veneniferas da jararaca (Bothrops jararaca) e da calçaca (Bothrops atrox) estariam nesse caso. As diferenças que se năo descobrem na forma e na estrutura dos citados orgãos, são reveladas pela compcsição química, pela dose minima mortal ou pelo modn de ação dos produtos quando inoculados no mesmo animal. Também certos microorganismos indistinguiveis que só se deixam reconhecer pelo fato de serem patogenicos ou inócuos, por viverem em hóspedes diferentes ou pelo seu comportamento em face de substâncias quimicas que desdobram ou fazem entrar em farmentação, só divergem pela constituiçăo. (Exemplos e bibliografia em ROBSON 1928). Tecidos e órgžos pertencentes a animais distintos podem, pois, ter a mesma forma e a mesma istrutura. A constituiçăo, porém, será tanto mais diferente quanto mais afastado for o parentesco zoológico dos seres qur: se comparam.

O pretoplasma é fundamentalmente o mesmo em toda a parte. como a vida é fundamentalmente a mesma onde quer que se manifeste. Mas, tanto o protoplasma como a vida diferam aspecificamente de conformidade com a diferenciaçáo que se proces:a quer no organismo que se desenvolve, quer na eipécie que evolui. E essa diferenciaçăo responsável pelas diver. gências ontogenéticas ou filogenéticas, onde quer que se oberve. Interessa sempre ao organismo todo. Duas espécies distintas nãn diferem sòmente pelos caracteres que o especialista do grilpo reconhece, mas integralmente. Tódas as suas partes, mismo acuelas indistinguiveis sob o ponto de vista da forma 
ju da estrutura, săo especificamente distintas. O mesmo se dá rom os elementos anatomicos que constituem o organismo. Uma cólula nervrsa e uma muscular, embora fundamentalmente formadas das mesmas partes essenciais, diferem integralmente pela especializaçáo. Sem perder qualquer de suas propriedaies essenciais o protoplasma se diferencia em células distintas, da mesma maneira que 0 ser vivo, sem perder as atributos da vida, se modifica para formar as espéLies. Uma célula nervosa e uma muscular do mesmo individuo são como dues espécies evoluidas de um ancestral comum : integralmente distintas. O citoplasma de uma é diferente do citoplasma da outra, assim como o núcleo de uma difere do nú.cleo da outra. O núcleo de uma célula nervosa difere do núclei de uma nélula muscular por todos os seus constituintes e assim. ieremos que os cromossomios da célula muscular são diferentes dos cromossómios da célula nervosa. E nem poderia ser de outra maneira. A diferenciaçáo é da célula toda e năo apenas c.e uma de suas partes. Nấo cabe nos conceitos da biologia a idéia de que só o citoplasma se diferencia, ficando o núcles. sempre o mesmo em thdas as células. Se fosse assim, poderiamos dizer que uma celula nervosa tem núcleo muscular ou uma célula muscular núcleo nervoso, o que seria absurdo. $O$ núcleo, na differenciaçáo celular, modifica-se tanto quanto o ajtoplasma. Os cromossomios, embora geralmente do mesmi aspecto, diferem de um tipo de cellula para outro. Numa célula nuscular eles săo cromossomios musculares, numa célula glandular săo glandulares. Bm cada tipo de células os cromosićmios desempenham uma funçăo especifica. Aliás, nžo seria cabivel aceitar que a funçăo dos cromossomios nas glandulas seja a mesma funçăo que têm os cromossomios nas células nervosas. Os gens, por conseguinte, trabalham diferentemente nas diversas partes do organismo.

A historia do desenvolvimento dos animals a partir do orí vai nos suxiliar a compreender o mecanismo da hereditariedadt Se acompanharmos a segmentaço de um ovo de anfíbio, material que escoinemos devido ao grande número de dados experimentals que pode nos oferecer, iremos cada vez maj; apreciando a inutilidade do conceito clássico da açăo dos gers.

o ovc dos Anuros apresenta dois hemisférios, um dos quais, $c$ hemisfério animal encerra o núcleo envolvido por citoplas:na pràticamente puro, ao passo que o outro, o hemisfério veBetativo, se acha tomado de vitelo, o qual, diminuindo de proporçăo, penetra até certo nivel no hemisfério animal, em cuja periferia se noia uma camada de substancia escura. Assim 
constituido, o óvo dos Anuros têm uma simetria radial, isto é, qualquer plano que passe pelo eixo que liga os dois polos o divide em duas partes sensivelmente iguais. As características dêsse óvo, deviuias sobretudo à grande quantidade do material vitelino acumulado num dos hemisférios e à situação do núcleo $\epsilon$ da substáncia escura no hemisfério oposto, năo dependem. de nenhum gen especifico. Sáo propriedades do óvo considerato como um todo. $\mathbf{E}$ visto que a extremidade anterior do emibriáo se forma do lado do pólo animal e a pösterior do lado do vegetativo, segue-se que essa primeira e importante deterninação relativa a posiçăo da cabeça e da cauda do futuro ser resulta da polaridade do óvo e independe da ação de gens.

O espermatozbide fecundante penetra no ovo em qualquer parte de uma faixa relativamente larga do hemisferio animal. A cabeça e a $\mathrm{p}$ ¿ça intermediária, avançando para o centro dêsse hemisfério: arrastam um pouco da substáncia escura da periferia. a qual fica por algum tempo assinalando o caminho po: elas percorrido A penetração do espermatozóide no 6vo provoca ta parte dêste as reaçóes que se traduzem por uma redistribuição das substâncias do citoplasma e que acabam pela determinaçăo da bilateralidade e da dorso-ventralidade do futuro nrganismo e bem assim pelo estabelecimento da posição do primeiro sulco de clivagem. (V. critica deste ponto em NEEDHAM 1912 p. 217 e seg.).

$T^{\prime}$ dos êsces fenómenos de alta significaçăo, que de mane:ra tão prematura determinam os lados direito e esquerdo, bem como as faces dosal e ventral do organismo que vem de inicia: - seu desenvolyımento, a despeito da sua enorme importancia, independem da ação especifica de gens. São uma simples consequéncia de um comportamento global bio-físico-químico di) sistem a representado pelo óvo. Esse primeiro conjunto de fe-nômenos se corclui pela divisão completa do ovo segundo um plano que passa pelo seu eixo, em dois blatómeros perfeitamerte iguais, rom o que se encerra definitivamente a primeira etapa da vida do organismo, ou seja, a sua fase uni-celular. $O$ organisino $f$ agora inteiramente diferente do que era antes, pois passoi a ser constituido por duas células que reagem entre si e com o me'o, uma delas formando a metade direito do seu corpo éa outra a metade esquerda. A face dorsal dessse organismo corresponde à face dorsal do ôvo e continua assinalada pela presenca do crescente cinzento que se formara nas proximidades do eq̣iador e em oposiçăo ao ponto de entrada do espermatosóide e que bissectado pela clivagem, repartiu-se, sem alterar a sun pojição. pelıs dois primeiros blastômeras. 
O segundo sulco divide o organismo de duas células por um plano longitudinal mediano perpendicular ao seu plano de simetría, transformando-o num organismo de quatro células, duas dorsais contendo a substancia do crescente cinzento e duas ventrals destituidas dessa substancia. enste organismo difere, por conseguinte, do precedente, por uma notável diferenclaçăo do citoplasma de suas células. Apesar de se achar contid em duas apenas das quatro células do organismo, a substancla do crescente cinzento é indispensável para que esse organlsmo. através le etapas sucessivas, chegue ao término de sua :evoluçáo, porquanto, sem ela, a gastrulaçăo năo seria possivel e a série de acontecimentos que se desenrolam a partir do ovo, mais cedo ou mais tarde seria interrompida. Isso nos mostra como o organtsmo, considerado como um todo funcional, depende de suas partes.

O organismo de quatro células, diferentes duas a duas pela constituiçદ̌o do seu citoplasma, se converte em um organismo de oito células, sendo quatro menores (micromeros) do lado do polo animal a quatro maiores (macromeras) do lado oposto. Essa diferença de tamanho entre as células anteriores e posteriores é mera consequencla de uma divisáo desigual e simultanea das quatro céluias do organismo que the deu origem. E essa divisão seg!nndo um plano que passa acima do equador das células é simplesmrnte devida à concentraçáo do vitelo no hemisferio vegetativo. Por conseguinte, tăo acentuada e caracteristica diferenciaçăo do embriáo de olto células é o resultado de uma conduta global do embriáo de quatro células, que se dividiu desigualmente em virtude de uma causa mecanica que nada tem que ver com uma atuaçăo especifica de gens.

Além dessa diferenciaçăo do tamanho das células, uma outra, de suma importancia para os fenomenos que se văo seguir e que igualmente náo é o trabalho de gens, refere-se à localização da substancia do crescente cinzento somente em dois dos quatro blastometros dorsais.

Depois de algum tempo todas as células do embriźo se dividen segundo um plano meridional e o embriáo se transforma em vm organismo de 16 células, 8 menores encimando 8 maiores. I.ogo a seguir as células dos dois grupos se dividem por um p'ano perpendicular ao da divisăo precedente e o embriăo passa a ser constituido por 32 células. Já se nota a partir desse momentc a influencia retardadora do vitelo nos blastomero: infericres. Daqui por diante as células pequenas passam a se multiplicar mais rapidamente que as grandes e tanto umas como outras perdem aquele ritmo inicial com que se di- 
vidiam. Dentro em pouco o embriáo se vê transformado numa blástula, ou seja, numa cavidade limitada em cima e dos lados por um grande número de celulas pequenas e tendo por assoaino um maciço formado por células que aumentam de tamanho dai para o pólo vegetativo.

Partindo do óvo e chegando à blástula vimos uma sucessáo de organismos diferentes, constituidos por um número cada vez maior de células, funcionando como organismos e como organismos dando origem a formas cada vez mais complexas, em que os elementos anatómicos se váo diferenciando de outros pela repartiçáo desigual de substancias contidas no citoplasma celular e que em consequência disso, sem deixarem de ser partes integrantes do todo que constituem, vão se comportanto diferentemente, uns se multiplicando mais depressa, outros mais devagar. $\mathrm{F}$ tudo isso, sem nenhuma intervençáo especifica de gens.

Os nucleos funcionam globalmente nas células em que se encontram e ainda plásticos, cada qual trabalha de acôrdo com os outros órgão: do sistema a que pertence, representado pelo citoplasma e pelas organelas e substâncias nêle contidas. Sendo todos iguais do ponto de vista gênico, os núcleos funcionam diferentemente segundo se acham numa célula pequena do pólo animal ou numa célula grande, carregada de vitelo, do pclo vegetativo. Tôda essa diferenciação que val do ôvo à blástula se processa sob a liderança do citoplasma, a cuja atividade o núcleo não faz mais que adatar-se. A segmentação do óvo é uma repetiçáo de processos globais de sistemas compostos por orgáos cada vez mais numerosos (células), nos quais citoplasma e núcleo funcionam por seu turno globalmente, como parter de sistemas menores. $O$ desenvolvimento ficaria bem definido com estas consideraçóes de WIEMAN (1930):

"The transformation of the single-celled fertilized egg inte the multicellular embryo is a manifestation of protoplasmic activity in which cell formation serves the function of increasing the size of the organism and segregating protoplasmic substances, as a preliminary step in the differentiation of tissues and organs." (Pag. 62).

Vimos que năo obstante passar por uma série de estádios diferentes o organismo do Anuro se val formando sem que se possa atribuir a qualquer gen a responsabilidade pelas diferenclaços assinaladas. Vejamos se daqui por diante os gens entram a trabalhar especificamente. 
Todác as células da blástula têm o seu destino traçado. Depois que VOGT (1929) demarcou-lhe à superficie as chamadas áreas presuntivas, tornou-se fácil aqueles que se acham famillarizados com o desenvolvimento embrionáro dos Anfíbios, reconhecer nelas as regibes que dentro em pouco deveráo inlciar a formaçáo da corda dorsal, da placa neural, da parte anterior e posterior do tubo digestivo, do tegumento, da mesoderme, das natas, dos olhos, dos ouvidos, enflm, das partes fundamentals (primordios) dos diferentes orgáos da futura larva. Para isso, torna-se, porém, necessária, uma alteraça na posição das células que formam a blástula, devendo umas se aprofundarem para constituir o encéfalo e a medula nervosa, o esqueleto e os músculos, o tubo digestivo, ficando outras à superfícle para formar a pele e parte dos orgkos dos sentidos: a ventosa, etc. Essa profunda modificaça começa por uma pequena depressão que se esboça medianamente na regiăo dorsal div blástula, no limite dos hemisférios, ou mais propriamente, na regiáo do crescente cinzento. As células da blástula, embora ainda năo diferencladas histológicamente e plásticas, pois que $n$ seu destino pode ser experimentalmente alterado, possuem no embriåo normal, uma determinaçáo especial. Se elas se mantiverem nas posiçбes que devem ocupar no decurso do desenvolvimento, acabarăo inevitàvelmente por se constitulrem nas partes do corpo que se esperam das áreas presuntivas a que pertencem. Isso nos faz antever a influencia que certas partes do corpo exercem na determinaçao de outras e o quanto a estrutura definitiva de uma célula depende de fatores extrinsecos.

Vimos um pouco acima, que na regizo do crescente cinzento, isto é, no ponto em que o meridiano dorsal da blástula cruza un: paralelo que passa a pequena distancia do equador, aparece uma depressáo que marca o inicio da gastrulaçăo.

Nos ovos em que o material vitelino acha-se mais ou menos unif.rmemente distribuido pelo citoplasma e em que, devido a isso, a segmentaçáo, sobbre ser total, pode ser mais ou menos igual, como no caso do Amphioxus, dando origem a uma blástulla provida de ampla cavidade limitada por uma só camada de células, a formação da gástrula se desenvolve de maneira bastante simples: - por invaginaçăo. A depressăo que se forma à superfícle (arquentério) vai-se aprofundando e invadindo a blastocele (cavidade de segmentaçăo), ate que as suas paredes se adatem às paredes daquela. Nos Anfíblos isso não é possivel em virtude do bloco espesso de células vitelinas que constituem a maior parte da blástula e que reduzem a blás- 
tocele a uma pequena caviciade do hemisfério animal. $O$ processo de gastrulação se desenvolve, pois, aqui, em grande parte, por epibolia. A cavidade inicial, estreita e arqueada para $\mathrm{C}$ pólo vegetativo, marca o coméço de uma invaginação incompleta em que sc̀mente as células de seu bordo superior se dobram para o interior. Issim se esboça, na área ocupada pelo crescente cinzento, o lábio dorsal do blastopório. Aprofundando-se cada vez mais e invadindo a blastocele as paredes do arquentério se vão distendendo para os lados e progressivamente envolvendo o maciço formado pelas células vitelinas. $O$ blastopório, cada vez mais arqueado, se completa e se reduz a um pequeno orifício circular obturado por um tampão vitelino. A gástrula está então, pràticamente completa e nela se podem reconhecer os tres folhetos germinativos, ou sejam, a ectoderme, a endoderme e a mesoderme.

Tóda a complicada série de acontecimentos que se terminam pela formação do organismo provido de um revestimento externo e de uma cavidade digestiva entre os quais se encontra a mesoderme. é a consequencia de um processo global por que passou o organismo primitivo, isto é, a blástula, e se deve a um estímulo inicial que parte da regiáo do crescente cinzento. Essa área, assinalada pelo lábio dorsal do blastopório, tem o. extraordinária propriedade de provocar, numa blástula normal, a formaçáo da cavidade que a transforma em gástrula. Sem $\cap$ crescente cinzento a gastrulaçáo náo seria possível, o que mostra que para se constituir uma gástrula são necessárias, no minims, dilas cousas : uma blástula capaz de reagir e uma substancis capaz de provocar a reaçăo. Essa substancia, contida nas células do crescente cinzento, mais uma vez nos mostra o quantc. o comportamento global do organismo pode depender da atividade especifica de uma parte limitada do seu corpo. Essa atividade năo se deve a gens. Os gens sendo os mesmos em toda parte e a gastrulaçăo começando sempre num determinado ponto da parede dorsal da blástula, torna-se evidente que a causa determinante desse fenómeno, que é uma causa. localizada, năo é genica. $\mathbf{E}$ a prova de que năo existem gens especificos atuando em determinado ponto da blástula para iniciar al a formaçáo da gástrula, está em que a transplantaçắn do lábio dorsal do blastopório de uma gástrula para diferentes áreas do corpo de uma outra, nelas provoca a gastrulaçăo, tomando parte no fenomeno (e isso é importante) náo só os tecidos do doador, mas também os do hospede. Há, por conseguinte, uma verdadeira indução exercida pelo tecido labial sóbre os tecidos da gástrula que o recebeu. Dessa gastru- 
laçăo induziđa pode resultar um embrižo secundário completo ao lado do embriáo normal, o que valeu ao láblo dorsal do blastoporio a denominaçzo de "organizador" que lhe deram SPEMANN \& MANGOLD.

* bastante claro que a açáo indutora, ou evocadora como alguns preferem, desenvolvida pelo organizador, næo é uma aça genica no sentido cĺ́ssico. Năo há gens para a gastrulaçăo c por conseguinte a induçăo da gástrula năo pode ser atribulda a uma sibstancia que se originasse do gen a maneira simplista com que, na opiniáo do genetista, aquela partícula miraculosa elabora um complexo quimico táo intrincado como seja por exemplo uma antocianina. Năo, aqui nơo há nenhuma "gastrulidina" de origem gênica. O que existe é uma substancia, especifica no sentido da induçăo que determina, produpida sómente por determinadas células da blástula. Estas células diferentes das outras, náo o săo pelos seus gens e sim pela composiç̧o do seu citoplasma. O citoplasma do ovo é diferen"ado e enquanto o núcleo, em todas as mitoses que efetua, se vai dividindo equacionalmente, dando sempre produtos do mesmo valor genético, o citoplasma val, desde o inicio, repartindo diferencialmente as substancias que contém. Somente as células que recebem o material do crescente cinzento e que vto formar o lábio dorsal do blastopórlo săo capazes de provocar a formaçăo de uma gástrula. Na ausencia dessa substancla. nue a experiêncla pode eliminar, nenhum gen será capaz de produzir outra dotada da mesma propriedade e năo haverá porisso gastrulaçáo. O evocador contido no citoplasma das células do lábio dorsal do blastoporio é uma substancia quimica, que exerce a sura açăo mesmo que as células que a possuiam tenham morrido. A transplantaçăo de tecidos mortos ou a inoculasăo de extratos, como se sabe, têm açáo indutora.

Até aqui os gens ainda năo agiram. Avancemos para ver se descobriremns o momento em que essas entidades entram em aça.

Se acompanharmos o desenvolvimento da gástrula vamos ver que cla se alonga e que aquelas áreas presuntivas assinalaladas à superficie da blástula, algumas das quais passaram para o interior, tomam a situaçăo dos orgzoos que futuramente Irzo formar. Medianamente na regio dorsal, logo acima do teto da caridade gástrica. constitul-se, na mesoderme do embriáo, a notsccida, assinalando a posiçăo da futura coluna vertebral. Por sćbre esta, na ectoderme, espessa-se a placa neural, que se transforma em goteira e depois em tubo destinado a dar origem as diferentes partes do sistema nervoso central. $O$ tubo 
neural produz lateralmente as vesiculas oculares, que se invaginarr. para formar as cápsulas oculares, defronte de cuja boca a epider:ne se modifica para constituir o cristalino. Um pouco para trás a epiderme dá, para dentro, origem às vesículas auditivas e forma, na região ventral da cabeça, as dobras que irăo constituir a ventosa. E assim, as branquias externas, os sacos nasais: o estomodeum (intestino anterior), o proctodeum (intestino posterior), a cauda, as patas anteriores e posteriores se văo esboçanco externamente de áreas presuntivas pré-estabelecicas, enquanto internamente os rudimentos do coraçăo, do fígado dos tubcs uriniferos e de outros orgáos văo por seu turno aparecendo. A arquitetura do organismo vai, desse modo, a pouco e pouco, delineando-se, à medida que os terrenos destinados à construção dos órgăos definitivos văo sendo demarcados. Nesse estado do desenvolvimento os orgáos săo representados pol rudimentos ainda náo conformados e histologicamente nấ diferenciados, o que quer dizer que eles ainda năo exibem nenhum traço marcante da estrutura que váo adquirir. Apesar disso, porém, cada esboço representa, desde já, o órgão que vai formar e nas condiçőes normais năo formará senåo esse órgž.o. Entretanto, como de acordo com a Idade da gástrula um esbóço transplantado para um regiăo diferente daquela em qie se constituiu pode alterar o seu destino para dar origem, de conformidace com a sua nova situaçáo, a um outro orgáo, segue-se, que abaixo de uma idade critica em que o destino do esbóço se estabelece de modo definitivo para năo mais ser alterado em situaçăo alguma, as áreas prospectivas ou rudimentos orgânicos só possuem uma determinaçăo que se pode chamar de "espacial" ou "de posiçâo". O futuro do esbóço que ainda năo alcançou a determinaçăo definitiva depende da sua posição no corro do embriḱo. Se ele conservar o lugar que the compete, acabará por perder a plasticidade e entáo virá a ser, irrevogàvclmente, o orgáo que dele se esperava, onde quer que seja levado a se desenvolver. Caso contrário, poderá dar formaçăo a um órgão inteiramente distinto.

A embriologia experimental demonstra que embora a zona mediana dorsal da gástrula possua uma certa tendencia para se invaginar independentemente e formar o tubo neural, nas condiçñes normais em que o desenvolvimento se processa esse tubo é induzido pelo contato das células da mesoderme que lhe ficam por baixn. Do mesmo modo, o contato da cápsula ocular com a ectoderme provoca a formaçáo, por parte desta, do cristalino. Sāo muitos os exemplos que poderfamos citar da açăo dos organizadores no desenvolvimento. Partes embrionárias que 
se våo diferanciando văo provocando a diferenciaça de outras. Sem a gástrulaçăo năo se poderia esperar a formaçăo do tubo neural e por conseguinte, do sistema nervoso, porque 0 desenvolvimento daqueje tubo depende do contato da ectoderme com a mesoderme axial que resulta da invaginaça das células do lábio dorsal do blastopório. Sem o tubo neural nto poderíanos esperar a formaçáo da vesicula ocular, porque asta năo passa de um diverticulo lateral da porça anterior daquele mesmo tubo. Sem a vesicula ocular ná teriamas um cristalino. porque este resulta de um contato da cápsula ocular oom a face interna da ectoderme adjacente. Há, por conseguinte, no orgar ismo, uma sérle bem concatenada de acontecimentos, cada um dos quais depende de um acontecimento anterior e provoca o acontecimento seguinte.

Os brgăas ou tecidos (organizadores) vio agindo uns sobre os outros por intermédio dos evocadores, que, como sabemos, sâo substáncias químicas. A evocaçăo do tubo neural se consegue, na.o somente com estratos do organizador respectivo, mas ate com substancias preparadas sinteticamente. Isso confirma a natureza quimica dos evocadores. $\mathrm{B}$ a ninguém consta que os evocadores sejam produtos genicas. Nă há gens especificos para a neurulaçấ do embriấ, nem também para a produçăo de uma cápsuia coular, de um cristalino, de um coraçáo ou de um $\boldsymbol{I}$ gado. Porém, mesmo que assim năo fosse, isto é, que existisse, por exerplo. nas células do primordio ocular, um gen cujo produto gozasse da propriedade de induzir as celulas ectodermais em crintîto con a cápsula ocular a modificarem a sua estrutura jara se converterem na lente do olho, mesmo assim chegariamos a resultados em desacordas com os preceitos estabelecidrs pela genétira clássica. De fato, sabe-se que a cápsula ocular transpla.itada para outras regibes do corpo da gastrula induz a formaçăo do cristalino onde a ectoderme, nas condiçôes normais. năo deveria formar esse orgăo. 0 mesmo acontece quando implantamos na área ocular do embriáo um fragmento de tecido de valor presuntivo diferente, o qual, ao contato ra cápsula ocular, se transformará em cristalino. $\mathrm{Em} \mathrm{ln}$ guágem genética esses resultados exprimem a maneira diversa do genótipo responder às influencias do melo organico, de conformidade com a situaçåo das células em que se encontram os gens. Assim, respondendo à atuaçăo deste ou daquele evocador, isto $\beta$, deste ou daquele meio, entram em atividade gens de patas, de ventosa, de branquias, de olhos, etc. Desse modo chegariainos a um resultado bastante interessante, que 60 seguinte: os gens sendo sempre os mesmos em toda a parte, 0 
que chama à atividade este ou aquêle gen é um avocador especifico (considerado para discussăo como um produto gênico) diferente em cada parte do embrião. Porém, a causa criadora dessa diferença năo encontra explicação nos arraiais da genética. Os motivos pelos quais na área presuntiva de olho trabalha o evocador de cristalino, na área de pata o evocador de pata, na de ventosa o de ventosa e assim por diante, o genetista năo saberé, explicar de maneira satisfatória. No entanto, a explicsçãc existe : é que os evocadores náo são produtos de gens especificos e sim substâncias elaboradas pela células funcionando como sistema, contidas no citoplasma e repartidas diferentemente.

Sabe-se, de outro lado, que depois de um certo tempo as áreas presuntivas do embriáo tornam-se definitivamente determinadas para só constituirem os orgáos a que se acham normalmente destinadas. Decorrido êsse tempo cessa a plasticidade do primórdio e o seu destino se fixa. Para onde quer que seja transportado, al dará êle origem àquele mesmo órgáo que daria se fôsse mantido na sua posiçăo original. Provam-no as repetidas experiências de transplantação de rudimentos dos mais diversos órgáos do embriǎo. Em linguágem genética isso quer dizer que os gens passam também por importantes transformuç̧ס̋s no decurso do desenvolvimento embrionário. No prinoíplo qualquer gen poderá indiferentemente entrar em atividade conforme o meio em que se encontrar a célula. Depois de algum tempc um certo gen recebe a determinaço definitiva e a partır dêsse momento êle se torna prepotente e nenhum outro será capaz de intervir para mudar o rumo por ele imprimido a.o esbóço que se desenvolve, o qual acabará por constituir o ćrgăo esperado onde quer que seja enxertado e a despeito da solicitaçăo exercida sobre outros gens pelos evocadores ativos na regiăo. Ejs aí um conceito embriologico novo, deduzido do medo de açấ dos gens : gens indeterminados ou plásticos e gens determinados.

Esse rápido escórço do desenvolvimento dos Anfíbios mostra-nos, sem que necessitemos discuti-las mais pormenorizadamente, as razóes pelas quais existe um periodo critico durante o qual os exbóços de orgăos se mostram sensiveis às açőes modificaduras do meio. 0 período da plasticidade. Antes da sua determinação definitiva o primórdio submetido aos agentes modifica.coris pode mudar o seu destino e transformar-se num orgăo difernnte. Uma vez determinado o orgáo como pata, como brânquia ou como ôlho, êle se constituirá em pata, brânquia ou olho, embora possa ser modificado em particularidades anato- 
micas que ainda năo receberam a determinaçăo. Quanto mais cedo na historia do desenvolvimento de um esboço atue o agente modificador, tanto mais generalizada, naturalmente, a modificaģo. Depois que todas as partes do órgåo que se desenvolve se acharem definitivamente determinadas, ainda assim ele podera sirr alterado em suas particularidades pelos fatores que agirem antes de se concluir a sua diferenciaçăo „histológlca. Concluida esta, so serk passivel alterar a forma e o volume do orgho. Istramos, portanto, de posse dos elementos que nos faráo compreender a produçáo das fenocóplas pela açăo da temperatura e de outros agentes e bem assim a maneira pela qual as nutaçoes alteram os caracteres do individuo. Pareceme, que tanto rum caso como no outro; o resultado obtido nzo se deve a uma alteraça da velocidade das reaçoes dos produtos genicss sperantes no organismo, como pretendem coldsCHMDT e seus adeptos. Se o desenvolvimento de uma estrutura lepende de um evocador e a produçáo deste se retarda, retarda-se igualmente o desenvolvimento de todas as estruturas que estiverem na dependencia de evocadores produzidos por aquela. Essa retardaçăo, contanto que nžo ultrapasse um certo limite toleravel, năo deve provocar nenhuma modificaçăo de estruturas. Alem do limite de tolerancia duas cousas podem ocorrnr : ou o esboço inicla a sua diferenclaçå sem o estimu10 do infutor e produz um órgáo rudimentar ou mal conformado, ou: perdendo a competencla, nás produs orgko algum. O que me parece multo pouca provavel e que o esbogo ainda indeterminado, em virtude de um auraso na produçáo do evocador que deve atingi-10; possa recehor a determinaça de outro evocador. Nas Anfibios isso nzo e possivel porque a evocaçåo se fas por contato do organizador com o esbogo que deve ser determinado. Nos Insetos o desenvolvimento depende de-substancias que se difundem pelo svo e depols pelo embribo. (SEIDEL 1936). Mas, que se sálba, essas substanclas n8o fazem senzo ativar esbogos determinados por processos que nzo foram ainda esclarecidos. Das inumeras axperiencias que se conhecem de transplantaça de discos Imaginais de todas as idades, pode-se concluir que a competencia dos primórdias de patas, de asas, de antenas, de olhos. de peças bucais, etc. 6 bastante limitada, o que fala em favor de uma determinaçáo intrinseca e maito precose desses órgáos por melo de substanclas năo difusítels contidas nas celulas dos respectivas asboços. Isso contraria as Idélas de GOLDBCEMIID relativas 20 modo de aglo dos gens difundindo no organismo as substancias que determinam as diferentes orghos: 
A determinaçáo sendo intrínseca como parece, 0 destino do esboço so pode mudar se se operar nas células que o constituem uma mocifficaçøo na composiçăo das substancias responsáveis pela determinaçåo ou uma substituiçăo de substancias. (Ct. PIZA 1941, 1945). Uma mutaçăo poderá produzir essse resultado e converter, por exemplo, uma antena em pata. Os fatores do melo e de modo particular a temperatura, podem influir de manefra acentuada sobre os fenomenos que se processam no organ!mo. aumentando ou diminuindo a solubilidade de certos corprs, ativando certas reaçoes, alterando a permeabilidade da membrana nuclear ou celular e desse modo permitindo a difusto de substancias que nas condiçoes normais deveriam permanecer retidas nas células em que se encontram. A conversán natural ou experimental de uma substancia determinadora nm outra ou a transposiça de substancias de um primordio indetermnado para outro sao, a meu ver, as causas das modificaçes estruturais do organismo devidas tanto as mutaçరes como às influencias do melo.

Vimos até agora que o desenvolvimento embrionário está quase concluido e a larva prestes a nascer e as gens ainda năo entraram com o seu trabalho especifico. Se a posiçăo da cabeça e da cauda é determinada sem o concurso de gens; se o dorso e o ventre e bem assim os lados direito e esquerdo săo determinados sem o concurso de gens; se a divisăo desigual das células ta biástula, a maior ou menor rapidez com que as células de cada hemisfério se multiplicam e a repartiçăo diferencial de substancias contidas no citoplasma independem da intervençăo te gens; se a gastrulação, a neurulaçăo, a subdivisăo do corpo embrionário em terrenos de valor prospectivo diferente, a determinaçáo definitiva dos esboços e por conseguinte a diferenc!açăo histológica dos órgžos se processam sem a intervençáo de gens especificos, é o caso de se perguntar para que servem entzo os gens ?

Para que servem os gens ? A resposta a essa pergunta vamos encortrar no estudo das galhas provocadas nas plantas pelos Insetos e, mais uma vez, na embriologia experimental.

Calhas saco excressencias produzidas pelas plantas e que servem para ahrigar, proteger e nutrir as larvas de certos insetos Formam-se nas mais diversas partes do vegetal (ramos. folhas, tuores, etc.), porém. sempre como resposta a um estimulo proveniente do inseto. Quer esse estimulo seja determinado por alguma substancia inoculada nos tecidos da planta por ocasiáo da pastura quer provenha do ovo em desenvolvimento, ou da larva em crescimento, o certo é, que a forma das 
galhas é tão característica para a espécie que a provoca, como qualquer te suas particularidades morfologicas ou anatómicas, servindo, porisso, muito bem, para a classificação. Onde quer que o inseto deposite o seu ôvo, seja numa flor, numa folha ou numa haste, de plantas da mesma espécie ou de espécies diferentes, al aparecerá sempre o mesmo tipo característico do galha. Pur conseguinte, embora todos os tecidos da galha pertençam à planto que a produziu, as suas características morfológicas são-lhe rigorosamente impostas pela açáo do evocador proveninnte do inseto. $\mathbf{E}$ que a forma da galha năo depende da planta e sim do inseto, vê-se também do fato de insetos perte'zcel.tes a espécies diferentes produzirem galhas diferentes na mosma plantic. Vemos daí que a faculdade de formar uma galha pertence inteiramerite ao organismo da planta. Ela a constitui ccin os seus tecidos, náo contribuindo o inseto com parcela alguma do material utilizdo na sua confecção. Entretanto o organisino vegetal obedece à risca ao plano arquitetónico traçado pelo inseto. $\mathbf{E}$, segundo $o$ inseto, isto $\hat{e}$, de conformidade com o plano êle construirá uma galha desta ou daquela forma. A parte fundamental da galha, ou seja, a sua estrutura, é obra exclusiva da planta; a forma depende do inseto.

Temos af um modêlo que nos auxilia a entender o papel que cabe aos gons na formação do organismo. Suponhamos tres espécies próximus de Opilizes, uma com a area III do escudo abdominal inteiramente desarmada, outra com essa área provida de dois tubérculos redondos e a terceira com dois altos espinhos na mesma situação dos dois tubérculos da segunda espécie. Enıhora nada saibamos a respeito da genética dos Opiliōes, n⿳⺈o seria descabida a assunçăo de que tubérculos e esplnhos que ornam o escudo de um grande numero de espectes, sejam. atributas gênicos. Uma mutação poderia dar um par de tubérculos a uma espécie de escudo primitivamente desarmado e uma outra poderia dar-lhe um par de espinhos altos e pontudos. Temcs aqui que os gens năo fazem senăo alterar a forma de uma estrutura preexistente, que num caso produz tubérculos e no outro espinhos. Trabalhando, portanto, num substrato cuja existência independe dêles, os gens seriam capazes de modelar as particularidades pelas quais o tegumento de uma espécie difere do tegumento de outra. O tegumento em si năo depande de gers. Porém se êle deve ser liso ou armado de pêlos, de tubérculos ou de espinhos, os gens podem decidir (Cf. PIZA 1941).

A embriologia experimental vem em auxilio das galhas para sos ajudar a compreender o papel desempenhado no or- 
ganismo pelos gens. Assim, se fizer-mos a transplantaçăo de um fragmento do tecido embrionário de Triton taeniatus destinado a formar as dobras neurais para a regizo lateral da cabeça de Triton cristatus. o tecido enxertado será induzido nessa nova situaçán a formar as branquias externas. Estas, porém, serăo do tipo das branquias da espécies que forneceu o enxerto (treniatus) e năo daquela que funcionou como hospede (cristatus). O tecido de taeniatus, portanto, que se destinava a produzir as dobras neurais se tivesse se conservado em sua situaçáo original, recebeu da parte de cristatus a mesma induçăo que receberia se fasse transplantado para o lado da cabeça de um embrişo da mesma espécie. Alís, sabemos que as organizadores agem inespecificamente, isto é, que o organizador de uma espécle é ativo para espécles diferentes, podendo o láblo dorsal do blantoporio de um Anuro determinar a formaçăo de um embriăo secundário na gástrula de um Urodelo. $O$ que o organize.dor faz è simplesmente induzir um esboço ainda năo determinadu a seguir na diferenciaçăo certo rumo. A cápsula ocular, por exemplo, induz qualquer parte da ectoderme a produzir um cristalino. mesmo que essa parte se destinasse a formar um orgzos bcm diferente. O organizador traça o destino do primórdio, sbrigando-o a se constituir em olho, ouvido, branquia, ventosa ru boca. Sobre as particularidades menores do orgăo induzide, ele năo influl. Essas particularidades fifam a cargo do tecidc que recebeu a induçáo. $O$ organizador extranho pode converter em branquias um primórdio de Triton cristatus que se destinava a produzir sistema nervoso. $O$ que ele náo pode, porém, é impor ao orgžo induzido caracteres outros que os da espécle de que proveio o primórdio. Um primórdio nso determinado será aquilo que o organizador fizer. Será branquia ou será slho, será o que for, mas terá as caracteristicas que teria se tivesse se desenvolvido no organismo que the deu origem. $E$ uma vez imposto o rum.o, o organizador delxa qo tecido enxertado a liberdade de produzir até mesmo os órgáos que a regizo induz:da nžo possuia na espécle que determinou a induça.o. Isso fira bem claro quando se enxerta eplderme presuntiva de Anuro na regía da boca de um embrizo de Urodelo. A epiderme enxertada se diferencia em boca, porém boca de Anuro, e produz usıa ventasa ventral que sómente os Anuros possuem.

Vê-se assim o que é que se pode esperar dos gens. Os gens imprimeni. segundo a proveniencia, as caracteristicas dos orgãos que se văo formando sem o seu concurso especifico. $O$ papel especifico dos gens se faz sentir apenas na forma, nas dimensōes, na coloração e em outras particularidades de 
meno: importancia de orgåos que se determinam por um mecanismo năo genico. Os organizadores formam e os gens conformam os orgăos. Os primeitos constroem os olhos, as ventosas, as patis ou a cauda; os segundos dăo a essas partes dn corpo os caracteres desta, daquela ou de ambas as espécies. variedadfs ou raças que contribuiram com o material com que se plasma o organisino.

Os conceltos de "campo morfogenético", de "campo de regeneraçăo" e de "gradiente", (Cf. SPBMANN 1936, HUXI.WY \& DE BEER 1934, WADINGTON 1940, NEEDHAM 1942), ainda mal compreendidos, porém, perfeitamente estabelecidos, contrariam an moilo mais cabal, a verbosidade simplista da genética. Se um orgăo qualquer, como por exemplo uma pata, se desenvolve pela açăo de produtos gênicos e sendo os gens sempre o: mismos em tódas aș células, năo se poderá explicar a existencia de campos vizinhos com potenclalidades organoformativas diferentes e bem assim a existencia de um gradiente de potencialidarie dentro de cada campo. Aqueles conceitos, porém. falam em favor da existencia de substancias náo difusivels no citoplasma das células. O gradiente poderia ser entåo - restiltado de uma divisăo mais rápida das cellulas da periferia do campo a tanto mais quanto menor se fosse tornando a concentraçăo de determinados elementos do citoplasma celular.

Firmemos agora o nasso conceito de gen. Em páginas anteriores procurámos mostrar que o gen năo deve existir como particula independente Os argumentos favoraveis ao gen corpuscular são muito frágels e pouco numerosos para contrabalançar os contrários. Evidencias das mais diversas ordens levam-nos a considerar o gen como uma funçăo do cromossomio, funçăo esta que ele desempenha como um todo. Dizer-se que um cromossomio possui n gens significa, para nos, que, em circurstancias ciferentes, o mesmo cromossomio pode exercer n atividedes distintas. Sob a influencla de um evocador de patas o cromossomio desempenha a sua funça "pata". Levado para c campo de açăo do evocador de olho o mesmo cromossómio passará a exercer a funçăo "olho". As translocaçбes, deficiencias e inversర̌es, transformam, em graus variávels, um todo em outro. Hsse novo todo poderá continuar a desempenhar as masmas atividades que tinha anteriormente, acrescidas de algunias que the foram induzidas pelo fragmento que recebeu como enxerto, pode perder algumas de suas funçбes, como pode adquirir propriedades inteiramente novas, isto é, que nenhum dos cromossómios envolvidos no fenomeno apresentava antes. 
Em un trabalho ariterior (PIZA 1941), tive a oportunidade de afirmar que "Um fragmento de cromossómio A desenvolvendo um complexo de atividades a pode soldar-se a uma fragmentc de $\mathbf{B}$ cujas atividades se traduzem por b. Originar-se-ia assim. um elemento composto, AB, cujas partes conservariam a sua independência morfológica, porém, reagindo uma sóbre a outra, produziriam um efeito genético diferente que poderia ser representado por c. Esse novo efeito (c) poderia mascarar completamente as efeitos a e b, poderia apenas atenuá-los, como poderia permitir a manifestação sòmente de um ou de outro em graus variáveis". (Pag. 27-28). Isso mesmo foi repetido nasconclusñes: "Uma translocaçăo tem a significaçăo de um enxêrto. Se o fragmento enxertado conserva uma certa independência funcional êle atua como um cromossomio deficiente. Se, pelo contrário, adere intimamente ao porta-enxerto, cada qual exerce sijbre o outro uma influência modificadora que pode traduzir-se por uma propriedade nova, que nenhum deles possuia separadamente". (Pag. 136). Esse mesmo topico foi repetido em inglês à pag. 137 : "A translocation has the significaiion of a grafting. If the grafted fragment maintains a certain functional independence it does act as a deficient choromosome. If, on the contrary, it adheres intimately to the host-chromosorze. each one exercises against the other a modifying influence which may be expressed by a new property not yet showed by none of them separately".

Essas conclusões de caráter meramente teórico a que cheguei foram recentemente confirmadas por um interessante trabalho de DOBZHANSKY (1946). Esse autor, analisando os produtos obtidos de crossing-over entre três chromossómios II da Drosophila pseudoobscura verificou que a troca de partes entre êsses cromossômios dava origem a efeitos genéticos inteiramente novos, que nenhum dos cromossómios possuia antes, quando im homozigose. A interpretaçáo de Dobzhansky para os efeitos que ele chamou de "sintéticos" é inteiramente clássica". Aliás, trata-se de um dos mais eminentes representantes vivos da teoría do gen-partícula. Seja, porém, qual for a explicação que se possa dar aos resultados experimentais por ele obtidis, èrses resultados têm para mim importante significação: confirmam objetıvamente a minha asserçăo segundo a qual um cromossómio resultante da fusăo de partes de dois outros, pode ter propriedades genéticas novas, isto é, que nenhum dêstes possula anteriormente. 


\section{SUMMARY}

In the present paper the classical concept of the corpuscular gene is dissected out in order to show the inconsistency of some genetical and cytological explanations based on it.

The 2.uthor begins by asking how do the genes perform their specific functions. Genetists say that colour in plants is sometimes due to the presence in the cytoplam of epidermal cells of an organic complex belonging to the anthocyanins and that this complex is produced by genes. The author then asks how can a gere produce an anthocyanin? In accordance to Haldane's view the first product of a gene may be a free copy of the gene Itself which is abandoned to the nucleus and then to the cytoplasm where it enters into reaction with other gene products. If, thus, the different substances which react in the cell for preparing the characters of the organism are coples of the genes then the chromosome must be very extravagant a thing : chain of the most diverse and heterogeneous substances (the genes) like agglutinins, precipitins, antibodies, hormones, e:zyms, coenzyms, proteins, hydrocarbons, acids, bases, salts, water soluble and insoluble substances! It would be very extrange that so a lot of chemical genes should not react with each othor. remaining on the contrary, indefinitely the same in spite of the possibility of approaching and touching due to the stati of extreme distension of the chromosomes mouving within tlie fluid medium of the resting nucleus. If a given medium becomes acid in virtue of the presence of a free copy of an ac'd gene. then gene and character must be essentially the same thing and the difference between genotype and phenotype disanpears, epigenesis gives up its place to preformation, and genetics goes back to its most remote beginnings.

The author discusses the complete lack of arguments in support of the view that genes are corpuscular entities. To show the emharracing situation of the genetist who defends the idea of corpuscular genes, Dobzhansky's (1944) assertions that "Discrete entities like genes may be integrated into systems, the chromosomes, functioning as such. The existence of organs and tissues does not preclude their cellular organization" are discussed. In the opinion of the present writer, afflrmations as such abrogate one of the most important characteristics of the genes, that is, their functional independence: Indeed, if the genes are independent, each one being capable of passing through mutational alterations or separating from its 
neighrours without changing them as Dobzhansky says, then the chromosome, genetically speaking, does not constitute a system. If on the other hand, the shromosome be really a system it will suffer, as such, the influence of the alteration or suppression of the elements integrating it, and in this case the genes cannot be independent. We have therefore to decide : either the chromosome is a system and th genes are not independent. or the genes are independent and the chromosome is not a sy:tem. What cannot surely exist is a system (the chromosome) formed by independent organs (the genes), as Dobzhansky admits. The parallel made by Dobzhansky between chromosomes and tissues seems to the author to be inadequate because we cannot compare heterogeneous things like a chromosome considered as a system made up by different organs (the gen:s), with a tissue formed, as we know, by the same organs (the cells) represented many times. The writer considers the cirromosome as a true system and therefore gives no credit to the genes as independent elements.

Genetists explain position effects in the following way: The products elaborated by the genes react with each other or with s'ibstances previously formed in the cell by the action of other gene products. Supposing that of two neighbouring genes $A$ and $B$, the former reacts with a certain substance of the cellular medium (X) giving a product $\mathbf{C}$ which will suffer the action of the latter (B). it follows that if the gene changes its position to a $\mathbf{D}$ !ace far apart from $\mathbf{A}$, the product it elaborates will spend more time for entering into contact with the substance $\mathbf{C}$ resulting from the action of $\mathbf{A}$ upon $\mathbf{X}$, whose concentration is greater in the proximities of $\mathbf{A}$. In this condition another gene produtc may anticipate the product of $\mathbf{B}$ in reacting with C, the normal course of reactions being altered from this time up.

Let we see how many incongruencies and contradictions exist in cuch an explanation. Firstly, it has been established by genetists that the reaction due to gene activities are specific and develon in a definite order, so that, each reaction prepares the medium for the following. Therefore, if the medium $\mathbf{C}$ resulting from the action of $\mathbf{A}$ upon $\mathbf{X}$ is the specific medium for the activity of $\mathbf{B}$, it follows that no other gene, in consequence of its specificity, can work in this medium. It is only after the interferc nce of $\mathbf{B}$, changing the medium, that a new gene may eiater into action. Since the genotype has not been modified by the change of the place of the gene, it is evident that the unique result we have to attend is a little delay without 
seious consequence in the beginning of the reaction of the product of $\mathbf{B}$ with its specific substratum C. This delay would be largely compensated by a greater amount of the substance $\mathbf{C}$ which the product of $\mathbf{B}$ should found already prepared. Moreover, the explanation did not take into account the fact that the genes work in the resting nucleus and that in this stage the chromosomes, very long and thin, form a network plunged into the nuclear sap. in which they are surely not still, changing from cell to cell and in the same cell from time to time, the distance separating any two genes of the same chromosome or of ilfferent ones.

The idea that the genes may react directly with each other and not hy means of their products, would lead to the concept of Go!dschmidt and Piza, in accordance to which the chromosomes function as wholes. Really, if a gene $\mathbf{B}$, accustomed to work between $A$ and $\mathbf{C}$ (as for instance in the chromosome ABCDEF), passes to function differently only because an inversion has transferred it to the neighbourhood of $\mathbf{F}$ (as in AED(BF), the gene $F$ must equally be changed since we cannot zimit that, of two reacting genes, only one is modified. The genes $\mathbf{E}$ and $\mathbf{A}$ will be altered in the same way due to the change of place, of the former. Assuming that any modification in a gene causes a compensatory modification in its neighbour in order $t$ : re-establich the equilibrium of the reactions, we crnclude that all the genes are modified in consequence of an inversion. The same would happen by mutations. The transformation of $B$ into $B^{\prime}$ would change $A$ and $\mathbf{C}$ into $A^{\prime}$ and $C^{\prime}$ respectively. The latter, reacting withD would transform it into $D$ ' and sion the whole chromosome would be modifled. A localized change would therefore transform a primitive whole $\mathbf{T}$ into a new one $\mathbf{T}$ ', as Piza pretends.

The attraction point-to-point by the chromosomes is denied by the present writer. Arguments and facts favouring the view that chromosomes attract one another as wholes are presenter. A fact which in the opinion of the author compromises sereously the idea of specific attraction gene-to-gene is found inthe $b$ havior of the mutated gene. As we know, in homozygosis, the same gene is represented twice in corresponding loci of the chromosomes. A mutation in one of them, sometimes so strong that it is capable of changing one sex into the opposite one or even killing the individual, has, notwithstading that, no effect on the previously existing mutual attraction of the corresponding loci. It seems reasonable to conclude that, if the genes $\mathbf{A}$ and $\mathbf{A}$ attract one another specifically, the attraction 
will disappear in consequence of the mutation. But, as in heterozygosis the genes continue to attract in the same way as before, it follows that the attraction is not specific and therefore dofs not be $\Rightarrow$ gene attribute. Since homologous genes attract one another whatever their constitution, how do we understand the lack cf attraction between non homologous genes or between the genes of the same chromosome?

Cnromosome pairing is considered as being submitted to the same principles which govern gametes copulation or conjugation of Ciliata. Modern researches on the mating types of Clliata offer a solid ground for such an intepretation. Chromosomes ronjugate like Clliata of the same variety, but of different mating types. In a cell there are $n$ different sorts of chroniosomes comparable to the varieties of Clliata of the same species which do not mate. Of each sort there are in the cell only two chromosomes belonging to different mating types (homologous chromosomes). The chromosomes which will conjugate (belonging to the same "variety" but to different "mating types") produce a gamone-like substance that promotes their union, being without action upon the other chromosomes. In this simple way a single substance brings forth the same result that in the case of point-to-point attraction would be reached through the cooperation of as many different substances as the genes present in the chromosome. The chromosomes like the Ciliata, divide many times before they conjuzate. (Gonial chromosomes) Like the Clliata, when they reach maturity, they copulate. (Cyte chromosomes). Again, like the Cillata which aggregate into clumps before mating, the chror:asrmes join together in one side of the nucleus before pairing. (Synizesis). Like the Ciliata which come out from the clumps paired two by two, the chromosomes leave the synizesis knot also in palrs. (Pachytene). The chromosomes, like the Ciliata, begin pairing at any part of their body. After some time ine latter adjust their mouths, the former their kinetochores. During conjugation the Culiata as well as the chromosomes exchange parts. Finally, the ones as the others separate to initiate a new cycle of divisions. It seems to the author that the analogies are to many to be overlooked.

When two chemical compounds react with one another, both are transformed and new products appear at the and of the reaction. In the reaction in which the protoplasm takes place, a sharp difference is to be noted. The protoplasm, contrarily to what happens with the chemical substances, does not enter directly into reaction, but by means of products of its physiologi- 
cal activities. More than that while the compounds with wich it reacts are changed, it preserves indefinitely its constitution. Here is one of the most important differences in the behavior of living and lifeless matter. Genes, accordingly, do not alter their constitution when they enter into reaction. Genetists contradict themselves when they affirm, on the one hand, that genes are entities which maintain indefinitely their chemical composition, and on the other hand, that mutation is a change in the chemica: composition of the genes. They are thus conferring to the genes properties of the living and the lifeless substances. The protoplasm, as we know, without changing its composition, can synthesize different kinds of compounds as enzyms, hormones, and the like. A mutation, in the opinion of the writer would then be a new property acquired by the protoplasm without altering its chemical composition.

With regard to the activities of the enzyms in the cells, the authnr writes: Due to the specificity of the enzyms we have that what determines the order in which they will enter into play is the chemical composition of the substances appearing in the protoplasm. Suppose that a nucleoprotein comes in relation to a protoplasm in which the following enzyms are present: a protease which breaks the nucleoprotein into protein and nucleic acid; a polynucleotidase which fragments the nucleic acid into nucleotids; a nucleotidase which decomposes the nucleotids into nucleosids and phosphoric acid; and, finally. a nucleosidase which attacs the nucleosids with production of sugar and purin or pyramidin bases. Now, it is crident that none of the enzyms which act on the nucleic acid and its products can enter into activity before the decomposition of the nucleoprotein by the protease present in the medium takes place. Lelkewise, the nucleosidase cannot works without the nuclentidase prevlously decomposing the nucleotids, neither the latter can act before the entering into activity of the polynuclentidase for liberating the nucleotids. The number of ensyms which may work at a time depends upon the substances present in the protoplasm. The start and the end of enzym activities, the direction of the reactions toward the decomposition or the synthesis of chemical compounds, the duration of the reactions, all are in the dependence respectively o fthe nature of the substances, of the end products being left in, or retired from the menlum, and of the amount of material present. The velocity of the reaction is conditioned by different factors as temperature, pF of the medium, and others. Genetists fall again into contradiction when they say that genes act like enzyms, 
controlling the reactions in the cells. They do not remember that to c ontroll a reaction means to mark its beginning, to doterm'ne its firection, to regulate its velocity, and to stop it Enzyms, as we have seen, enjoy none of these properties improperly attributer to them. If, therefore, genes work like enzyms, they do not controll reactions, being, on the contrary, controlled by substonces and conditions present in the protoplasm. A gene. like on enzym, cannot go into play, in the absence of the substance te which it is specific.

The genes are considered as having two roles in the organism one preparing the characters attributed to them and other, preparing the medium for the activities of other genes. At the first glance it seems that only the former is specific. But. if we consider that each gene acts only when the appropriated medium is prepared for $1 t$, it follows that the medium is as specific to the genc as the gene to the medium. The author concludes fiom the analysis of the manner in which genes perform their function, that all the genes work at the same time anywhere in thr organism, and that every character results from the activities of all the genes. A gene does therefore not await for a given medium because it is always in the appropriated medium. If the substratum in which it opperates changes, its activity changes correspondingly. Genes are permanently at work. It is true that they attend for an adequate medium to develop a certain act'vity. But this does not mean that it is resting while the required cellular environment is being prepared. It never rests. While attending for certain conditions, it opperates in the prer:ous cnes it passes from medium to medium, from activity to activity, without stopping anywhere.

Genetists are acquainted with situations in which the attended results do not appear. To solve these situations they use to make appea! to the interference of other genes (modifiers, suppressors, activators, intensifiers, dilutors, a. s. o.), nothing else doing in this manner than displacing the problem. To make genetcal systems function genetists confer to their hypothetical entities truly rijaculous faculties. To affirm as they do $w^{*}$ th so great a simnlicity, that a gene produces an anthocyanin, an enzym, a hormone, or the like, is attribute to the gene activities that inly very complex structures like cells or glands would be capab.e of producing Genetists try to avoid this difficulty advancing trat the gene works in collaboration with all the other genes as well as with the cytoplasm. Of course, such an affirmation merely means that what works at each time is not the gene, but the whoie cell. Consequently, if it is the whole cell 
which is at work in every situation, it follows that the complete set of genes are permanently in activity, their activity changing in accordance with the part of the organism in which they are working.

Transplantation experiments carried out between creeper and normal fowl embryos are discussed in order to show that there is ro loca! gene action, at least in some cases in which geneists use to recognize such an action. The author thinks that the pleintropism concept should be applied only to the effects and not to the causes. A pleiotropic gene would be one that in a single actuation upon a more primitive structure were capable of prorucing by means of secondary influences a multiple effect This definition, however, does not preclude localized gene action, only displacing it. But, if genetics goes back to the egg and puts in it the starting point for all events which in course of development finish by producing the visible characters of the organism, this will signify a great progress.

From the analysis of the results of the study of the pheniscoples the author concludes that agents other than genes being also capable of determining the same characters as the genes, these entities lose much of their credit as the unique makers of the organism.

Insisting ahout some points already discussed, the author lays once more stress upon the manner in which the genes exercise their activities, emphasizing that the complete set of genes works jnintly in collaboration with the other elements of the cell, and that this work changes with development in the different parts of the organism. To defend this point of view the author start,s from the premiss that a nerve cell is different from a muscle cell. Taking this for granted the author continues saying that those cells have been differentiated as systems, that is all their parts have been changed during development. The nucleus of the nerve cell is therefore different from the nucleus of the muscle cell not only in shape, but also in function. Though fundamentally forned by th same parts, these cells differ integra!ly from one another by the specialization. Without losing anyone of its essenial properties the protoplasm differentiates itself into distinct kinds of cells, as the living beings differentiate into species. The modifled cells within the organism are comparable to the modifled organisms within the species. A nerve and a muscle cell of the same organism are therefore like two specles originated from a common ancestor: integrally distinct. Like the cytoplasm, the nucleus of a nerve cell differs from the one of a muscle cell in all peculari- 
ties and accordingly, nerve cell chromosomes are different from muscle cell chromosomes. We cannot understand differentiation of a part only of a cell. The differentiation must be of the whole cell as a system. When a cell in the course of development becomes a nerve cell or a muscle cell, it undoubtedly arquires nerve cell or muscle cell cytoplasm and nucleus respectively. It is not admissible that the cytoplasm has been changed alone, the nucleus remaining the same in both kinds of cells. It is therefore legitimate to conclude that nerve ceil has nerve cell chromosomes and muscle cell, muscle cell chromosomes. Consequently, the genes, representing as they do, specific functions of the chromossomes, are different in different sor $: s$ of cells.

After having discussed the development of the Amphibian egg on the light of modern researches, the author says : We have seen tiil now that the development of the egg is almost finished and the larva about to become a free-swimming tadepole and, notwithstanding this, the genes have not yet entered with their specific work. If the haed and tall position is determined without the concourse of the genes; if dorso-ventrality and bilaterality of the embryo are not due to specific gene actions; if the uripqual division of the blastula cells, the different speed with which the cells multiply in each hemisphere, and the differential renartition of the substances present in the cytoplasm, all this do not depend on genes; if gastrulation, neurulation. division of the embryo body into morphogenetic fields. definitive determination of primordia, and histological differentiation of the organism go on without the specific cooperation of the genes, it is the case of asking to what then the genes serve?

Based on the mechanism of plant galls formation by gall insects and on the manner in which organizers and their products exercise their activities in the developing organism, the author interprets gene action in the following way: The genes alter structures which have been formed without their specific intervention. Working in one substratum whose existence does not depend $o$ nthem, the genes would be capable of modelling in it the particularities which make it characteristic for a given individual. Thus, the tegument of an animal, as a fundamental structure of the organism, is not due to gene action, but the prescnce or absence of hair, scales, tubercles, spines, the colour or any other particularities of the skin, may be decided by the genes. The organizer decides whether a primordium will be eye or gill. The details of these organs, however, are left to 
the genetic potentiality of the tissue which received the induction. For instance, Urodele mouth organizer induces Anura presumptive epidermis to develop into mouth. But, this mouth will be farhioned in the Anura manner.

Finalizing the author presents his own concept of the genes. The genes are not independent material particles charged with specific activities, but specific functions of the whole chromosome. To say that a given chromosome has $\mathbf{n}$ genes means that this chromonome, in different circumstances, may exercise $\mathbf{n}$ distinct activities. Thus, under the influence of a leg evocator the chromosome, as whole, develops its "leg" actlvity, while whitun the field of influence of an eye evocator it will develop its "eye" activity. Translocations, deficiencies and inversions will transform more or less deeply a whole into another one, This new whole may continue to produce the same activities it had formerly in addition to those wich may have been induced by the grafted fragment, may lose some functions or acquire entirely new properties. that is, properties that none of them had previously. The theoretical possibility of the chromosomes acquiring new genetical properties in consequence of an exchange of parts pnstulated by the present writer has been experimentally confirmed by Dobzhansky, who verifled that, when any two Drosophila pseudoobscura II - chromosomes exchange parts, the chossover chromosomes show new "synthetic" genetical effects.

\section{LITERATURA CITADA}

BOWEN, R. H. - 1929 - The Quart. Rev. Biol. 4 : 299-324, 484519.

BRACHFT, J. - 1944 - Embryologie chimique. Masson \& Cle., Ed. Paris.

BRINK, R. A - 1929 - The Quart. Rev. Biol. 4 : 520-543.

CAIRNS, J. M. - 1941 - J. Exp. Zool. 88 : 481-500.

CALKINS, G. N. - 1926 - The Biology of the Protozoa. Lea \& Febiger. Philadelphia and New York.

CARSON, H. L. - 1944 - J. Morph. $75:$ 11-59.

CARSON, ㅂ. L. - 1946 - Genetics 31 : 95-116. 
CHIARU(AI, G. - 1929 - Trattato di Embriologia. Soc. Edt Libraria. Mllano - Parte Prima.

DOBZHANSKY, Th. - 1941 - Gentics and the Orjgen of Species Columbia Un. Press. New York.

DOBZHANSKY. Th. - 1943 - Rev. de Agr. $18: 387--396$.

DOBZHANSKY, Th. - 1946 - Genetics 31 : 269-290.

GAYER, K. and V. HAMBURGER - 1943 - J. Exp. Zool. 93 : 147-194.

GOLDSCHMIDT, R. - 1938 - Physiological Genetics. McGraw. Eill Dook Comp. Inc. New York and London.

GOLDSCHMIDT, R. - 1940 - The material basis of Evolution Yale IJn. Press. New Haven.

GOLISCF!MIDT, R. - 1946 - Experientia (Separatum), Vol I/6: $1-40$.

HALDANE, J. B. S. - 1941 - New Paths in Genetics. Geors: Allen \& Unwin Imtd. London.

HAMBURGER, V. - 1942 - Biol. Symp. 6 : 311-336.

HINTON, T. - 1946 - J. Hered. - 37 :99-102.

HUXILEY, J. S. and G. R. DE BEFR - 1934 - The elements of experimental Embryology. Cambridge, At the Un. Press.

Jennings, H. S. - 1938 - Proc. Nat. Acad. Sc. 24 : 112-120.

JENNINGS, H. S. - 1939 - Genetics 24 : 202-233.

JENNINGS, H. ऽ. - 1939a - Amer. Nat. 73 : 414-431.

JENNINGS, H. S. - 1942 - Biol. Symp. 8 : 105-119.

Rnsearch. Columbia Un. Press. New York. 710-771.

JENNINGS, H. S. 1942 - Biol. Symp. 8 : 105-119.

JOHANNSEN W - 1926 - Elemente der exakten Erblichkelre. Gustav Fischer, Jena. 
JUST. F. E. - 1939 - The blology of the cell surface. P. Blakiston's Son \& Co., Inc. Philadelphia.

KIMBAL.L, R. F. - 1939 - Amer. Nat. 73 : 451-456.

KIMBAL:, R. F. - 1943 - The Quart. Rev. Biol. 18 : 30-45.

KODANI, M - 1942 - J. Hered. 33 : 115-133.

KUDO, R. R. - 1931 - Handbook of Protozoology. Charles C. Thomas. Publ. Springfield (Illinois) and Baltimore (Maryland).

LIILIF, F' R. - 1923 - Problems of fertilization. The Un. of Chicago Press, Illinois.

MC CLINTOCK, B. - 1945 - Am. Journ. Bot. 32 : 671-678.

MINCHIN, E. A. - 1922 - An introduction to the study of the Protozoa. Edward Arnold, London.

MOR(aAN, Th. H. - 1924 - In Cowdry's General Cytology. Un. Chicago Press, Chicago, Illinois, 692-734.

MORGAN, Th. H. 1927 - Experimental Embryology. Columb.a Un. Press. New York.

MORGAN, Th. H. - 1934 - Embryology and Genetics. Columb:a Un. Press. New York.

NEEDHAIM, J. - 1942 - Blochemistry and Morphogenesis. Cambridge, At the Un. Press.

OPARIN, A. I. - 1938 - The origin of life. The Macm. Comp. New York.

PIZA, S. de Toledo Jor. - 1930 - Localizaçáo dos factores na linina nuclear como base de uma nova theoria sobre a hereditariedade. Irmáos Perches \& Cia. Piracicaba.

PJZA, S. Je Toledo, Jor. - 1941 - O citoplasma e o núcleo no desenvolvimento e na hereditariedade. Tip. Jornal de Plracicaba. 
PIZA, S. de To!edo, Jor. - 1942 - Rev. de Agr. 17 : 154-168.

PIZA, S. Je Toledo, Jor. - 1944 - Rev. de Agr. 19 : 26-50.

PIZA, S. te Toledo, Jor. - 1946 - Rev. de Agr. 21 : 359-360.

PIZA, S. de Toledo, Jor. - 1946a - An. Esc. Sup. Agr. "Luiz d? Queiroz" 3 : 339-346.

PIZA. S. de Toledo, Jor. - 1946b - An. Esc. Sup. Agr. "Luiz de Queiroz" 3: 27-54.

PIZA, S. de Toledo, Jor. - 1946c - An. Esc. Sup. Agr. "Luiz d? Queiroz" 3 : 141-148.

REICHENOW. E. - 1929 - Lehrbuch der Protozoenkunde. Gustav Fischer. Jena.

RIS, H. - 1؟ 15 - Biol. Bull. 89 : 242-257.

RIS, H. and Helen CROUSE - 1945 - Proc. Nat. Acad. Sc. 31 : 321-337.

ROBSON, G. C. - 1928 - The species problem. Oliver and Boyd: Edinburgh and London.

SEIDEL. F. - 1936 - Verhandl. Deut. Zool. Gesell. Zool. Anz. 9. Suppl. Bd : 291-336.

SONNERORN. T. M. - 1937 - Proc. Nat. Acad. Sc. 23 : 378-385.

SONNieBORN, T. M. - 1938 - Proc. Amer. Phil. Soc. 79 : 411-434.

SONNERORN, T. M. - 1939 - Coll. Net. $14:$ 77-84.

SONNEBORN, T. M. - 1939a - Amer. Nat. 73 : 390-413.

SONNEBORN, T. M. - 1941 - In Calkins' Protozoa in Biological Research. Columbia Un. Press. New York. 666-709.

SPEMANN, F. - 195ò - Experimentelle Beiträge zu einer Theorie der Entwicklung. J. Springer. Berlin.

STERN C. - 1936 - Amer. Nat. $70:$ 29-35.

STURTEVANT, A. H. - 1945 - Genetics 30 : 297-299. 
STURTEVANT, A. H. and C. W. BEADLE - 1940 - An introducton to Genetics. W. B. Sounders Company. Philadelphia and Londors.

SWANSON, C. P. - 1943 - Bot. Gas. 105 : 108-112.

VOGT. W. - 1929 -Arch. Entwmech. 120 : 385-706.

WADINGTON, C H. - 1940 - Organizers \& Genes. Cambridge, At the un. Press.

WIEMAN. H L. - 1930 - An introduction to vertebrate embryology. McGraw-Hill Book Company, Inc. New York and London.

WILSON, E. B. - 1925 - The cell in development and heredity. The Vacm. Comp. New. York. 